\title{
"Relations Stop Nowhere": ERISA Preemption of San Francisco's Domestic Partner Ordinance
}

\author{
Emily V. Griffen
}

When Congress passed the Employee Retirement Income Security Act in 1974, and included a broadly-worded preemption clause stating that the Act supersedes any state law that "relates to" employee benefits, they could not have anticipated how far-reaching the Act would be. Twenty-four years later, ERISA's preemption clause hindered the enforcement of a revolutionary local ordinance. San Francisco's Equal Benefits Ordinance requires city contractors to provide domestic partner benefits to their employees equal to those provided to married workers. A legal challenge brought by United Airlines and the Air Transport Association sought to invalidate the Ordinance based on ERISA preemption. Even though the Supreme Court in recent cases has narrowed ERISA's preemptive reach by looking beyond the preemption clause to the goals behind the Act, the Court has not been able to fully free itself from the clause's broad language. Based on this Supreme Court authority, the district court held that San Francisco could not require airlines to provide certain ERISA benefits such as health care to domestic partners of their employees. This Comment argues that ERISA should not preempt local laws like San Francisco's that seek to provide equality in the workplace. Legislative error created an irrationally broad preemption clause that prevents local regulation in areas of employee benefits with which ERISA is not concerned. Further, judicial efforts to minimize the law's preemptive effect have proved unavailing. Therefore, ERISA's preemption clause should be legislatively deleted to allow local laws to operate in areas not addressed by the federal act.

Copyright $(2001$ California Law Review, Inc. California Law Review, Inc. (CLR) is a California nonprofit corporation. CLR and the authors are solely responsible for the content of their publications.

$\dagger$ Associate, Shearman \& Sterling, San Francisco. J.D., School of Law, University of Califomia, Berkeley (Boalt Hall), 2000. B.A., Amherst College, 1996. I will be a law clerk for U.S. District Court Judge Claudia Wilken in Oakland for the 2001-2002 term. I would like to thank Elizabeth Kristen and the editors of the California Law Review for their hard work and thoughtful editing suggestions. I would also like to thank Sage Andersen, whose wisdom, strength, and support guided me through this process. 


\section{INTRODUCTION}

In 1974, Congress enacted the Employee Retirement Income Security Act ("ERISA"). ${ }^{1}$ The Act was passed to ensure that employee retirement benefits would be available to those employees that had contributed to such benefit plans. ${ }^{2}$ Before ERISA was enacted, numerous problems had arisen in the administration of these benefit plan funds. ${ }^{3}$ Regulation was left primarily to the states, and the lack of a nationally uniform standard resulted in poor administration, fraud, and the drying-up of pension plans. ${ }^{4}$ Thus, many employees that participated in such plans lost retirement benefits because their pension plan terminated with insufficient assets to meet all of the fund's obligations..$^{5}$ ERISA aimed to protect benefit plan participants from such hardship by creating funding standards, requiring disclosure and reporting of financial information to participants, enacting participation and vesting requirements, and creating fiduciary responsibility on the part of pension plan administrators. ${ }^{6}$

Twenty-three years later, on June 1, 1997, a first-of-its-kind ordinance took effect in the City and County of San Francisco. Dubbed the Equal Benefits Ordinance ("Ordinance"), the municipal law requires any company that does business with the City of San Francisco to offer the same benefits to the domestic partners of its employees as it does to spouses of its employees. ${ }^{7}$

San Francisco's Board of Supervisors, which drafted and passed the Ordinance, praised it as a key move in providing equality in the workplace because it prevents discrimination in compensation on the basis of sexual orientation and marital status. ${ }^{8}$ The Ordinance's definition of benefits is nonexclusive, including not only health benefits but bereavement and family medical leave, ineinbership discounts, moving expenses, pensions and retirement benefits, and travel benefits. ${ }^{9}$ Because benefits of this kind can account for inore than twenty-five percent of an employee's earnings, ${ }^{10}$ unmarried couples in a committed relationship with a domestic partner (either same or opposite sex) are, in a sense, being paid less than their

1. 29 U.S.C. $\$ \S 1001-1461$ (1994).

2. See id. $\S 1001(\mathrm{~b})$.

3. See infra note 29 and accompanying text.

4. See infra note 29 .

5. See infra note 29 .

6. See infra notes 30-33 and accompanying text.

7. S.F., CAL., ADMin. Code § 12B.1 (1998).

8. See infra Part II.

9. S.F., CAL., Admin. Code § 12B.1(b).

10. See Charles S. Mishkind et al., Employee Benefits Litigation, in Litigating EMPLOYMENT Discrimination Cases: 1996, at 223, 231 (PLI Litig. \& Admin. Practice Course Handbook Series No. 542,1996 ) (noting that employers spend more than $25 \%$ of their total compensation costs on employee benefits). 
married co-workers for the same amount of work. It is this inequality that San Francisco sought to prevent in passing the Ordinance.

Almost immediately, several organizations that had contracts with San Francisco attacked the Ordinance." The strongest challenge to the Ordinance came from United Airlines, which refused to comply with the law's domestic partner benefits requirements. ${ }^{12}$ At the time the Ordinance took effect, United had just begun new construction on its leased land at San Francisco International Airport ("SFO"), owned by the City. ${ }^{13}$ In its negotiations for a new twenty-five year lease, United resisted including a provision requiring the airline to give benefits to the domestic partners of its employees. ${ }^{14}$ San Francisco officials, pursuant to the Ordinance, refused to enter into a new contract with United absent this provision. Having reached an impasse, the Air Transport Association of America ("ATA"), representing United and other airlines at SFO, filed suit against the City in federal court in May $1997 .^{15}$

ATA's suit against the City relied on several theories, but the most important and arguably most successful was that the Ordinance is preempted by ERISA. ${ }^{16}$ Preemption invalidates state or local laws that diminish the effect of, or threaten the goals of, federal laws. ${ }^{17}$ At first glance, it seems almost absurd that an antidiscrimination law such as the Ordinance would interfere with ERISA. The two laws appear to have very little im common. Although both act within the general realm of employee benefits, ERISA addresses protection for pension plan participants, while the Ordinance combats discrimination in the provision of employee benefits to employees' beneficiaries. The connection between the two does not seem powerful enough to require invalidation of the Ordinance in order to ensure the effectiveness of federal law. Yet, the ERISA preemption argument in ATA's suit against the City was successful and has resulted in partial invalidation of the Ordinance. ${ }^{18}$ Therefore, United and other airlines

11. See infra notes 12,90 .

12. See Deb Price, San Francisco Values All People with Its Domestic-Partnership Law for City Contracts, DETROrr News, Feb. 21, 1997, at E2, available at http://detnews.com/1997/accent/9702/21/02210035.htm; Victoria Slind-Flor, Church, Airlines Balk At Benefits Law: San Francisco's Domestic Partners Law Causes Big Stir, NAT'L L.J., Feb. 17, 1997, at A6.

13. Martha Irvine, Domestic Partners Law Has Airline in Bind, SAN DiEgo UnIon-TrIB., Feb. 3, 1997, at A3.

14. Price, supra note 12; Slind-Flor, supra note 12.

15. Air Transp. Ass'n of Am. v. City of San Francisco, 992 F. Supp. 1149 (N.D. Cal. 1998).

16. See discussion infra Part II.A.2.

17. See, e.g., Enghish v. Gen. Elec. Co., 496 U.S. 72,78 (1990) (summarizing three types of preemption: explict preemption, field preemption, and conflict preemption).

18. See ATA, 992 F. Supp. at 1180. 
at SFO currently do not have to provide health and other ERISA benefits to the domestic partners of their employees. ${ }^{19}$

The scope of ERISA preemption, in this case, was great enough to curtail the effects of a municipal ordinance intended to provide equality in the provision of employee benefits. This is nothing new in the area of ERISA preemption, a complex and controversial subject. ${ }^{20}$ The reason for the Act's seemingly irrational preemptive scope can be found in section 514(a), the Act's preemption clause, which states that the law "shall supersede any and all State laws insofar as they may now or hereafter relate to any employee benefit plan."21 This expansive clause invalidates any law that may relate to any employee benefit plan, even though ERISA's substantive provisions only cover narrow issues of fiduciary duties, disclosure mandates, and participation and vesting requirements. ${ }^{22}$ While thus preventing any state or local attempts to improve employee benefits, the statute does not protect plan participants and beneficiaries by requiring employers to provide minimum benefits of any kind. ${ }^{23}$

ERISA's broad preeinption clause for many years resulted in a correspondingly broad understanding of the statute's preemptive reach by courts. ${ }^{24}$ Only recently has the Supreme Court begun to rein in ERISA's preemptive scope in any meaningful way. In the last few years, three Supreine Court cases have found state laws not to be preempted by ERISA. $^{25}$ These cases have indicated that ERISA preemption is not as farreaching as once interpreted, as the Court has applied a inore commonsense, traditional approach to preemption, looking to the imtent of Congress in passing the law. Nevertheless, ERISA preemption still threatens to invalidate laws like the San Francisco Ordinance. Thus, ERISA still throws a large preemptive shadow over state and local law-1naking.

ERISA's statutory language leads inevitably to an overbroad judicial interpretation of its preemptive effect. It would require an unduly forced

19. Relying on the Airline Deregulation Act, the court also held that if Uinted can show that the burden of providing non-ERISA benefits (such as bereavement leave and fiight discounts) would be so great that it would coerce the airline to change its routes to avoid operating at SFO, it would not need to provide those benefits either. See id. at 1187 . United filed a new suit to avoid providing these benefits in October 1998, but District Court Judge Claudia Wilken rejected this clain. Air Transp. Ass'n v. City of San Francisco, No. C97-01763CW, 1999 U.S. Dist. LEX1S 8747 (N.D. Cal. May 27, 1999).

20. ERISA preemption is a notoriously difficult and confusing area of law. As one judge put it, "any court forced to enter the ERISA preemption thicket sets out on a treacherous path." Gonzales v. Prudential Ins. Co. of Am., 901 F.2d 446, $451-52$ (5th Cir. 1990) (King, J.).

21. Section 514(a) is codified at 29 U.S.C. $\$ 1144$ (a) (1994).

22. See 29 U.S.C. $\$ 1001$ (b) (1994); see also infra Part 1.A.

23. See infra Part 1.A.

24. See infra Part 1.B.

25. See De Buono v. NYSA-ILA Med. \& Clinical Servs. Fund, 520 U.S. 806 (1997); Cahf. Div. of Labor Standards Enforcement v. Dillingham Constr., N.A., 519 U.S. 316 (1997); N.Y. State Conference of Blue Cross \& Blue Shicld Plans v. Travelers Ins. Co., 514 U.S. 645 (1995); see also discussion infra Part II.C. 
reading of the plain statutory text to find that the Act does not preempt an ordinance that, practically speaking, mandates a certam structure for employee benefit plans. Instead of arguing for such a reading, I take San Francisco's Ordinance as an example of the problems inherent in ERISA's expansive preemption clause, and the need for a legislative solution in the form of an ainendinent to section 514(a).

Local and state governments should be able to pass laws which provide equality in the workplace and benefit local citizens. Local governinents, under our federal system, must be able to provide equality and protection for their constituents as they see fit, as long as doing so does not conflict with or hinder federal goals or policies. This is especially true in the area of antidiscrimination laws and civil rights protections, since much legislation of this type originates on the local or state level before being implemented nationally. ${ }^{26}$ San Francisco passed the Equal Benefits Ordinance to eliminate discrimination in the workplace on the basis of sexual orientation and marital status. ${ }^{27}$ Iromically, ERISA and the Ordinance are, in a broad sense, attempting to accomplish the same goal, protecting employees and encouraging equality in the provision of employee benefits. Yet the Ordinance itself does not toucli any of the issues actually addressed by ERISA; in fact, the Ordinance has almost nothing to do with the administration of einployee benefit plans, except to define wlio may be a beneficiary. ERISA is not concerned with defining who may be covered under an ERISA plan, but is instead interested in protecting plan beneficiaries froin fraud and loss of accumulated benefits, primarily im the area of pension plans, issues far removed frow the Ordinance's effects. This raises concerns that ERISA's preemptive scope is irrationally broad.

The Supreme Court's recent narrowing of ERISA's preemptive reach has resuscitated the possibility of judicial correction of this problem. But judicial interpretation currently inust ignore the statute's broad preemptive langnage in order to rein in ERISA to a meaningful degree. Furthermore, even this recent judicial creativity does not appear to protect laws like the

26. See infra notes 143-151 and accompanying text.

27. Federal law currently does not prohibit discrimination in employnent on the basis of sexual orientation or marital status. See infra note 151 and accompanying text. The Ordinance requires companies to give benefits to both same-sex and opposite-sex domestic partners, but one of the clear aims of the Board of Supervisors was to protect same-sex couples who are unable to marry. As two of the Supervisors noted, the Ordinance is only an extension of the City's current policy of requiring nondiscrimination in all contracts made with private companies (including nondiscrimination on the basis of sexual orientation, doinestic partner status, and marital status). See Leslie Katz \& Tom Ammiano, Letters to the Editor, S.F. EXAMINER, Jan. 31, 1997, at A22; see also S.F., CAL., Admin. CODE $\S 12 B .1(a)$ (1998).

The Board of Supervisors and the City Attorney have consistently referred to the Ordinance as a law intended to combat discrimination and provide equality in the workplace. See, e.g., Jason B. Johnson, S.F., Gay Rights Groups Support Boycott Against United, S.F. CHRON., Dec. 15, 1998, at A25 (quoting Supervisor Mark Leno as saying "[a]ll we're asking for are equal benefits for equal work"); Rinat Fried, Gay Workers Ask United For Benefits, REconder, Oct. 2, 1998, at 1. 
Ordinance, which mandate benefit plan structures. Because judicial interpretation cannot go far enough in protecting important local laws from preemption, congressional revision of the Act is the only feasible option if such laws are to stand.

The problem at the heart of ERISA preeinption is one of statutory creation. Congress erred when it created a federal law that covered a narrow range of issues, and then proceeded to preempt the entire field of employee benefit plans. That field is largely unregulated and untouchable, since states cannot pass any law that relates to einployee benefit plans. ERISA's preemption clause should be legislatively deleted so that courts can apply traditional preemption principles that will do justice to the objectives of ERISA and the interests of states. This would allow room for local governments to pass laws that provide equality in the workplace for their citizens.

Part I of this paper examines the development and evolution of ERISA preemption doctrine, highlighting the Supreme Court's recent narrowing of ERISA's preemptive scope. Part II describes San Francisco's Equal Benefits Ordinance and gives a brief history of the enactment of the Ordinance and opposition to it. This Part also examines ATA's suit against the City, focusing on the district court's ERISA analysis, and assesses the ruling, concluding that courts currently cannot avoid finding local laws preempted by ERISA when they require benefit plans to contain certain provisions. Next, this Part explores why ERISA preemption is dangerous as it applies to Ordinances like San Francisco's, and presents reasons that the Ordinance should not be preeinpted. Part III examines problems inherent in ERISA preemption, both legislative and judicial, especially as they affect preemption of domestic partner ordinances. Part IV proposes solutions to the problem of ERISA preemption of San Francisco's Ordinance, concluding that a legislative amendinent is more viable than a judicial solution. Congress must delete ERISA's preemption clause to allow state and local governments like San Francisco to protect their employees from discrimination in the workplace.

I

\section{BACKGROUND ON ERISA PREEMPTION}

\section{A. Goals of ERISA}

Congress enacted the Employee Retirement Income Security Act in 1974 to protect participants in einployee pension and benefit plans. ${ }^{28} \mathrm{Be}-$ fore 1974, the states were primarily responsible for regulation of such plans and federal legislators were concerned that poor administration, fraud, and the premature depletion of pension plans were injuring einployees

28. See 29 U.S.C. $\$ 1001$ (1994); see also infra note 33 and accompanying text. 
participating in such plans. ${ }^{29}$ Thus, ERISA was enacted to protect benefit plan participants by creating uniform, national regulations surrounding employee benefit and pension plan administration.

ERISA's provisions include participation and vesting requirements, funding standards, and reporting and disclosure guidelines for covered plans. ${ }^{30}$ The Act creates fiduciary responsibility and standards of conduct for plan administrators. ${ }^{31}$ Congress also provided for federal remedies, such as exclusive federal jurisdiction, for violations of ERISA. ${ }^{32}$ These provisions are meant to secure realization of ERISA's stated purpose which is to

protect... the interests of participants in einployee benefit plans and their beneficiaries, by requiring the disclosure and reporting to participants and beneficiaries of financial and other information with respect thereto, by establishing standards of conduct, responsibility, and obhigation for fiduciaries of employee benefit plans, and by providing for appropriate remedies, sanctions, and ready access to the Federal courts. ${ }^{33}$

While ERISA covers employee welfare plans that provide health, medical, surgical, and hospital care benefits, its provisions act, as its title and stated purpose suggest, primarily to protect and secure employee pension plans. Thus, while welfare plans are inentioned in ERISA, they are negligibly regulated, whereas the field of pension plans is regulated coinpletely, by providing standards and requireinents for pension plan administration. ${ }^{34}$

Congress focused on creating a uniform set of standards for employee welfare and pension plans in order to facilitate protection of einployees by eliminating the need for employers to adhere to inconsistent state and local regulations. ${ }^{35}$ This goal of uniformity was accomplished in section 514(a),

29. See 29 U.S.C. $\$ 1001$ (a) ("[D]espite the enormous growth in such plans many employees with long years of employment are losing anticipated retirement benefits owing to the lack of vesting provisions in such plans."); see also 120 CoNG. REc. S29,950 (1974) (statement of Sen. Bentsen) ("Government statistics indicate that during 1972 alone more than 15,000 pension plan participants lost retirement benefits because their pension plan terminated with insufficient assets to meet all plan obligations.").

30. 29 U.S.C. $\S \S 1001(\mathrm{~b}), 1021-1031,1053-1086$.

31. Id. $\S \S 1002(21)(\mathrm{A}), 1104,1109$.

32. Id. $\$ 1132$.

33. Id. $\$ 1001(\mathrm{~b})$.

34. See id.

35. See 120 CoNG. REC. H29,197 (1974) (statement of Rep. Dent) ("With the preemption of the field, we round out the protection afforded participants by eliminating the threat of conflicting and inconsistent State and local regulation."); id. at 29,933 (statement of Sen. Williams) ("It should be stressed that with the narrow exceptions specified in the bill, the substantive and enforcement provisions ... are intended to preempt the field for Federal regulations, thus eliminating the threat of conflicting or inconsistent State and local regulation of employee benefit plans."); id. at 29,942 (statement of Sen. Javits) ("[T]he emergence of a comprehensive and pervasive Federal interest and the interests of uniformity with respect to interstate plans required... the displacement of State action in the field of private employee benefit programs."). 
ERISA's preemption clause, which provides that the Act's provisions "shall supersede any and all State laws insofar as they now or hereafter relate to any employee benefit plan."36 Employee benefit plans, for purposes of the Act, include both welfare plans and pension plans (although the term "benefit plan" is also often used synonymously with "welfare plan," meaning plans that provide benefits such as health care).$^{37}$ ERISA's broad preemption language has led to extensive litigation in the Supreme Court and other federal courts to determine when a state or local law "relate[s] to" employee benefit plans for purposes of federal preemption.

\section{B. Traditional ERISA Preemption Doctrine Under Shaw}

Preemption of state and local laws by federal law falls into two major categories: express and implied preemption. Express preemption is statutorily based, and exists when a federal law contains an explicit preemption clause describing the extent to which it predominates over similar state laws. ${ }^{38}$ Implied preemption applies when Congress has legislated in a certain field, and state or local laws impacting the same field are unconstitutional under the Supremacy Clause because they impermissibly step into an arena already defined by federal law. ${ }^{39}$ Whether preemption is

36. 29 U.S.C. $\$ 1144$ (a). Other provisions provide exemptions from preemption for certain laws, such as a state's insurance laws. See, e.g., id. $\$ 1144(\mathrm{~b})(2),(4),(7)$. ERISA defines "state law" broadly, to include "all laws, decisions, rules, regulations, or other State action having the effect of law." Id. § 1144(c)(1). Further, a "state" is defined as "a State, any political subdivision thereof, or any agency or instrumentality of either, which purports to regulate, directly or indirectly, the terms and conditions of einployee benefit plans covered by this subchapter." Id. $\S 1144(\mathrm{c})(2)$. Thus, ERISA's preemption clause explicitly applies to inunicipal ordinances like San Francisco's, when and if they "relate to" employee benefit plans.

37. See id. $\$ 1003($ a). ERISA defines "employee pension benefit plan" and "pension plan" as: any plan, fund or program which was heretofore or is hereafter established or inaintained by an einployer or by an einployee organization, or by both, to the extent that by its express terms or as a result of surrounding cireumstances such plan, fund, or program (i) provides retirement income to einployees, or (ii) results in a deferral of income by einployees for periods extending to the termination of covered employment or beyond, regardless of the method of calculating the contributions inade to the plan, the method of calculating the benefits under the plan or the method of distributing benefits from the plan.

Id. $\$ 1002(2)(\mathrm{A})$.

ERISA defines "employee welfare benefit plan" and "welfare plan" as:

any plan, fund, or program which was heretofore or is hereafter established or maintained by an employer or by an employee organization, or by both, to the extent that such plan, fund, or program was established or is maintained for the purpose of providing for its participants or their beneficiaries, through the purchase of insurance or otherwise, (A) medical, surgical, or hospital care or benefits, or benefits in the event of sickness, accident, disability, death or unemployment, or vacation benefits, apprenticeship or other training programs, or day care centers, scholarship funds, or prepaid legal services ....

Id. $\$ 1002(1)$.

38. See, e.g., Mich. Canners \& Freezers Ass'n v. Agric. Mktg. \& Bargaining Bd., 467 U.S. 461, 469 (1984) (describing express preemption); see also Elaine M. Martin, Note, The Burger Court and Preemption Doctrine: Federalism in the Balance, 60 NoTRE DAME L. REv. 1233, 1235 (1985) (defining express preeinption).

39. See U.S. ConST. art. VI, cl. 2. 
express or implied, the ultimate factor in determining if a state law is preempted by a federal act is the intent of Congress in passing the federal legislation. ${ }^{40}$

ERISA's explicit preemption clause seems to make preemption decisions easy, smce it broadly encompasses any state regulation that "relate[s] to any employee benefit plan."4l Early Umited States Supreme Court decisions read this clause expansively, and preempted any state regulation that related to employee benefit plans in any way. The best example of early ERISA preemption analysis is Shaw v. Delta Air Lines, Inc. ${ }^{42}$ In Shaw, several employers challenged two New York State laws under ERISA. The plaintiffs claimed that New York's Human Rights Law, which forbade discrimination in employment including discrimination in einployee benefit plans on the basis of pregnancy, and New York's Disability Benefits Law, which required employers to pay sick-leave benefits to pregnant employees, were preempted by ERISA. ${ }^{43}$ The Court in Shaw provided a framework for ERISA preemption by stating that "[a] law 'relates to' an employee benefit plan, in the normal sense of the phrase, if it has a connection with or reference to such a plan."44 Later cases use this two-part "connection with" or "reference to" inquiry to determine whether a particular law "relates to" employee benefit plans for purposes of ERISA preemption. The Court in Shaw, however, did not conduct such an inquiry, since it had "no difficulty in concluding that the Human Rights Law and Disability Benefits Law 'relate to' employee benefit plans." 45

The Supreme Court in Shaw held that New York's Human Rights Law was preempted by ERISA to the extent that it prohibited practices that are not unlawful under federal law, namely Title VII of the Civil Rights

This Constitution, and the Laws of the United States which shall be made in Pursuance thereof; and all Treaties made, or which shall be nuade, under the Authority of the United States, shall be the supreme Law of the Land; and the Judges in every State shall be bound thereby, any Thing im the Constitution or Laws of any State to the Contrary notwithstanding. Id. Implied preenution takes two forms: conflict and field preemption. See infra note 199; see also Martin, supra note 38, at 1235-36 (discussing conflict and field preemption principles).

40. E.g., Laurie F. Hasencamp, ERISA and Preemption of State Fair Employment Laws, 59 S. CAL. L. REv. 583, $587 \mathrm{n.24}$ (1986) ('[C]ongressional intent is therefore the key inquiry in deciding whether federal legislation preempts certain state laws.") (citing Shaw v. Delta Air Lines, Inc., 463 U.S. 85 (1983)); Ray v. Atlantic Richfield Co., 435 U.S. 151, 157-58 (1978); see also Martin, supra note 38, at 1236 (discussing the need to look at federal objectives to determine the proper scope of preeniption).

41. 29 U.S.C. $\$ 1144$ (a) (1994).

42. 463 U.S. 85 (1983).

43. See id. at 88 .

44. Id. at $96-97$.

45. The Court reasoned:

Enuploying this definition [that the phrase "relate to" ineans "a connection with or reference to"], the Human Rights Law, which prohibits einployers from structuring their eniployee benefit plans in a manner that discriminates on the basis of pregnancy, and the Disability Benefits Law, which requires employers to pay employees specific benefits, clearly 'relate to' Id. at 97 . benefit plans. 
Act of $1964 .^{46}$ This is because Title VII relies on state laws for aid in enforcement of its employment discrimination prohibitions, and preemption of state laws that prohibit the same practices prohibited by Title VII would "impair" federal law. ${ }^{47}$ But where a state law prohibits practices that are not unlawful under federal law (such as pregnancy discrimination before the Pregnancy Discrimination Act was enacted in $1978,{ }^{48}$ or marital status and sexual orientation discrimination today ${ }^{49}$ ), preeinption by ERISA is appropriate since it would not impair federal law..$^{50}$ Thus, New York largely could not enforce its pregnancy nondiscrimination provisions through regulation of ERISA-covered benefit plans (which includes inost employers' health plans).

Other Supreme Court decisions have also found ERISA's preemption clause to be extremely broad in reach. In Pilot Life Insurance Co. $v$. Dedeaux, an insurance company argned that an employee's state common law contract and tort claims were preempted by ERISA. ${ }^{51}$ The Supreme Court held that the state suit asserting improper processing of the employee's claim for benefits under an ERISA-regulated plan was preempted by ERISA, primarily because Congress intended ERISA's civil enforcement scheme to be exclusive. ${ }^{52}$ The Court pointed out that "the express preemption provisions of ERISA are deliberately expansive." "Similarly, in FMC Corp. v. Holliday, the Supreme Court found that a Pennsylvania law relating to reimbursement of benefits from tort recovery funds satisfied the broad Shaw preemption test because the law had both a "connection with" and a "reference to" employee benefit plans. ${ }^{54}$ These laws were

46. See id. at 108-09; see also Title VII of the Civil Rights Act of $1964 \S 703,42$ U.S.C. $\S \S 2000 \mathrm{e}-2$ (1994); infra note 151 and accompanying text. The Court in Shaw held that while the Disability Benefits Law relates to employee benefit plans, it is exempt from ERISA preemption because it is a "disability insurance law" under $\S 4(b)(3)$, as long as New York does not enforce the law through regulation of ERISA-covered plans. See Shaw, 463 U.S. at 108-09 (finding only separately administered disability plans maintained solely to conply with the Disability Benefits Law are exempt from ERISA coverage under $\S 4(\mathrm{~b})(3)$ ).

47. See 29 U.S.C. § 1144(d) (1994) (providing that section 514(a) shall not "be construed to alter, amend, modify, invalidate, impair, or supersede any law of the United States").

48. See Pregnancy Discrimination Act of 1978, Pub. L. No. 95-555, 92 Stat. 2076 (codified at 42 U.S.C. § 2000e(k) (1994)); see also Shaw, 463 U.S. at 89 ("Until [the Pregnancy Discrimination] Act took effect on April 29, 1979, the Human Rights Law in this respect had a reach broader than Title VII.") (citations omitted).

49. See infra notes $145-151$ and accompanying text (discussing the absence of federal law prohibiting sexual orientation or marital status discrimination).

50. See Shaw, 463 U.S. at 103 ("Insofar as state laws prohibit employment practices that are lawful under Title VII, however, pre-emption would not impair Title VII within the meaning of $\S$ 514(d).").

51. 481 U.S. 41 (1987).

52. See id. at 57.

53. Id. at $45-46$.

54. 498 U.S. 52,59 (1990). 
invalidated even though neither addressed issues central to the Act such as pension plan fund security or administration.

These early ERISA preemption cases illustrate the Court's expansive interpretation of ERISA's preemption clause language. There seemed to be a striking willimguess on the part of the Supreme Court to invalidate even those state laws that had a remote relationship to employee benefit plans, and often no relationship to the issues actually covered by the Act. In Shaw, for instance, the Court refused to limit preemption to "state laws dealing with the subject matters covered by ERISA - reporting, disclosure, fiduciary responsibility, and the like." ${ }^{.55}$ The Court also considered and rejected the idea that ERISA preemption should be limited to those state laws "specifically designed to affect employee benefit plans."

This practice of reading "relate[s] to" in its broadest sense continued in District of Columbia v. Greater Washington Board of Trade, where the Court held that a law that specifically referred to ERISA plans related to ERISA plans for preemption purposes. ${ }^{57}$ In Greater Washington, a nonprofit corporation challenged a D.C. law that required an employer to provide workers' compensation benefits equivalent to their existing health insurance coverage. Although the D.C. law sought to enhance employee benefits and protections, the Supreme Court held it preempted by ERISA because the coverage required was "measured by reference to" the employers' ERISA-covered plans. ${ }^{58}$ In Greater Washington, like in Shaw, the Court held that ERISA required imvalidation of a state law that purported to protect employees, the primary goal of ERISA itself. The Court made this requirement explicit in Metropolitan Life Insurance Co. $v$. Massachusetts, asserting that the "pre-emption provision was intended to displace all state laws that fall within its sphere, even including state laws that are consistent with ERISA's substantive requirements." 59

ERISA preemption reached its zenith im a line of cases that invalidated not only state laws consistent with ERISA's objectives, but also those having an indirect effect on ERISA-covered plans. In Alessi $v$. Raybestos-Manhattan, Inc., for instance, the Supreme Court held that "even imdirect state action bearing on private pensions may encroach upon the area of exclusive federal concern." $" 60$ The Court in Alessi invalidated a

55. Shaw, 463 U.S. at 98 .

56. Id.

57. 506 U.S. 125,130 (1992).

58. Id. at 130.

59. 471 U.S. 724, 739 (1985). The Court in Metropolitan Life found a Massachusetts law requiring minimum mental health benefits to be a law regulating insurance, and thus explicitly exempted from ERISA's preemption clause. Id. at 758; see also Mackey v. Lanier Collection Agency \& Serv., Inc., 486 U.S. 825 (1988) (invalidating a Georgia statute that expressly refers to ERISA plans (exempting them froin a state garnishment statute) because it singled out ERISA plans for special treatinent).

60. 451 U.S. 504,525 (1981). 
New Jersey law that eliminated a certain method for calculating pension benefits under plans governed by ERISA, since pension plan regulation is a federal concern under the Act. The Court so held even though the law had only an indirect effect on ERISA plans and did not impede ERISA's objectives.

Traditional ERISA preemption doctrine, while expansive, was not without complexity. In Shaw, the paradigmatic case for expansive, almost unquestioning ERISA preemption, the Court qualified its holding (although in a footnote) by pointing out that "[s]ome state actions may affect einployee benefit plans in too tenuous, remote, or peripheral a manner to warrant a finding that the law 'relates to' the plan."61 It was this opening, albeit small, that the Court used as a starting point in reformulating ERISA preemption doctrine towards a more narrow interpretation.

\section{New ERISA Preemption Doctrine Under Travelers and Its Progeny}

In 1995, the Supreme Court began to take a more restrictive approach to ERISA preemption in New York State Conference of Blue Cross \& Blue Shield Plans v. Travelers Insurance Co. ${ }^{62}$ The law at issue in Travelers was a New York statute that imposed surcharges on hospital rates for certain commercial health insurers and HMOs, but exempted Blue Cross and Blue Shield plans. ${ }^{63}$ The law was challenged by several commercial insurers because it indirectly affected the cost of certain employee health care plans that are governed by ERISA. ${ }^{64}$

The Court in Travelers applied the two-part analysis to ERISA preemption as stated in Shaw, asking whether the New York law inakes "reference to" or has a "connection with" ERISA plans. ${ }^{65}$ Determining that the law does not make explicit reference to ERISA plans (which would almost always result in preemption), the Court inoved on to the "connection with" test. The Court altered its traditional approach to ERISA preemption by starting with a presumption against preemption of state laws. ${ }^{66}$ The Court backed away from its earlier, expansive approach, recognizing that "relate to" has no clear stopping point. As the Court admitted: "If 'relate to' were taken to extend to the furthest stretch of its indeterminacy, then for all practical purposes pre-emption would never run its course, for 'really, universally, relations stop nowhere.",67

61. Shaw, 463 U.S. at 100 n.21.

62. 514 U.S. 645 (1995).

63. See id. at 649 .

64. See id. at 651-52.

65. See id. at 656.

66. See id. at 654 ("[W]e have never assumed lightly that Congress has derogated state regulation, but instead have addressed claims of pre-emption with the starting presumption that Congress does not intend to supplant state law.").

67. Id. at 655 . 
The above analysis illustrates that the Travelers Court recognized that interpreting ERISA's boundless preemption clause language literally can provide absurd and unintended results. In a crucial passage, the Court rejected its earlier "uncritical literalism" emption in a new inanner, by moving away from an attempt to interpret the "relates to" phrase: "We simply must go beyond the unhelpful text and the frustrating difficulty of defining its key term, and look instead to the objectives of the ERISA statute as a guide to the scope of the state law that Congress understood would survive." 69

The focus of analysis shifted to the practical objectives of ERISA and its preemption clause, whicl the Court determined was to "avoid a multiplicity of regulation in order to permit the nationally uniform administration of employee benefit plans." ${ }^{.70}$ The Court found that the law at issue in Travelers affected ERISA plans, but only indirectly, by clianging the incentives and costs of employee benefit plans. ${ }^{71}$ This was not enough to find the law preennted by the Act, for "an indirect economic influence ... does not bind plan administrators to any particular choice... [or] preclude uniform administrative practice or the provision of a uniform interstate benefit package." 72

In Travelers the Court changed direction considerably by acknowledging the difficulty of interpreting ERISA's all-encompassing preemption clause in a reasonable inanner. In a sense, the Court abandoned any attempt to interpret section 514(a)'s language, and applied a traditional implied preemption analysis, by beginning with a presumption against preemption and proceeding to examine the intent of Congress to determine the scope of federal law vis-à-vis state law. Yet at the same time, the Court refused to overrule its earlier ERISA decisions that paid liomage to the plain language of the preemption clause and that invalidated all laws that had any connection with or reference to employee benefit plans, however slight. ${ }^{73}$ The Court walks a thin lime in Travelers, pointing ERISA preemption in a new, more common-sense direction that focuses less on the text of the preemption clause and inore on congressional objectives, while also refusing to acknowledge the disparity between this analysis and its earlier, literal textualism. This refusal to explicitly overrule earlier cases will be addressed later, for it limits the transformative impact of Travelers, tlus preventing a law like the San Francisco Ordinance from avoiding preemption. ${ }^{74}$

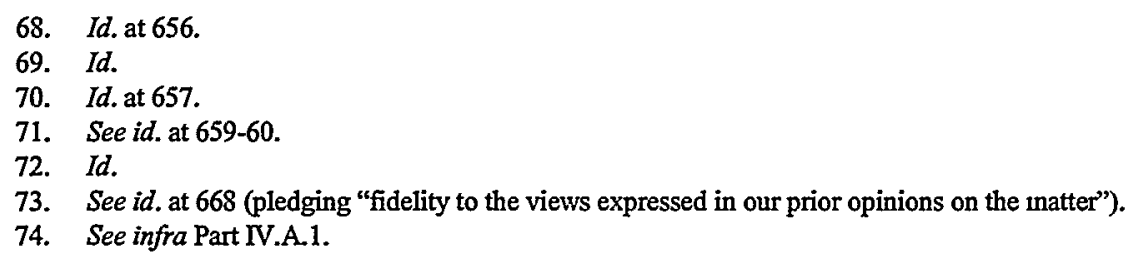


In 1997, two other Supreme Court cases took the same new, more critical approach to ERISA preemption as Travelers. ${ }^{75}$ In California Division of Labor Standards Enforcement v. Dillingham Construction, $N . A$., a plaintiff challenged California's prevailing wage law, which allows the payment of wages below the prevailing wage to employees participating in state-approved apprenticeship programs, as preempted by ERISA. ${ }^{76}$ The Court held that the California law does not have a "connection with" and thus does not "relate to" ERISA plans for purposes of preeinption. ${ }^{77}$

Like Travelers, the Court described its ERISA preemption analysis as a two-part inquiry that asks whether a law has a "connection with" and "reference to" an ERISA-covered employee benefit plan. ${ }^{78}$ When a law, like the California law at issue in Dillingham, does not refer specifically to ERISA plans, the only inquiry is whether it has a connection with such plans. ${ }^{79}$ Although the Court summarized several of its earlier cases that found ERISA's preemption provision "clearly expansive," 80 it then relied on Travelers" new formulation of the "connection with" test, which focuses on congressional objectives instead of textual literalism. ${ }^{81}$ Dillingham also followed Travelers' presumption against preemption by assuming that a federal law does not supersede state law "unless that was the clear and manifest purpose of Congress." $" 82$

The Court in Dillingham concluded that the California law at issue was more like the New York surcharge program upheld in Travelers than

75. See De Buono v. NYSA-ILA Med. \& Clinical Servs. Fund, 520 U.S. 806 (1997); Cal. Div. of Labor Standards Enforcement v. Dillingham Constr., N.A., 519 U.S. 316 (1997). In a third case decided in 1997, Boggs v. Boggs, the Court acknowledged its new approach to ERISA preemption as stated in Travelers, but nonetheless found a Louisiana law allowing testamentary transfers of interest in ERISA plans preempted by ERISA. 520 U.S. 833 (1997). Importantly, the Court in Boggs chose to apply traditional conflict preemption to the Louisiana law at issue, see id. at 841 , following the concurrence in Dillingham which stated: "I think it accurately describes our current ERISA jurisprudence to say that we apply ordinary field pre-emption, and, of course, ordinary conflict pre-emption. Nothing more mysterious than that; and except as establishing that, 'relates to' is irrelevant." Dillingham, 519 U.S. at 335 (Scalia, J., concurring) (citations omitted). This move toward applying traditional preemption principles will be addressed later.

76. 519 U.S. 316 (1997).

77. Id. at 333 .

78. See id. at 323 .

79. See id. at 325 .

80. Id. at 323 .

81. See id. at 325. The Court quotes Massachusetts v. Morash, an earlier Supreme Court ERISA preemption case, which stated the objectives of Congress as follows:

In enacting ERISA, Congress' primary concern was with the misinanagement of funds accumulated to finance employee benefits and the failure to pay employee benefits from accumulated funds. To that end, it established extensive reporting, disclosure, and fiduciary duty requirements to insure against the possibility that the employee's expectation of the benefit would be defeated through poor management by the plan administrator.

Id. at 327 (quoting Morash, 490 U.S. 107, 115 (1989)).

82. Id. at 325 (quoting Travelers, 514 U.S. at 655 ). 
other laws that had been invalidated by ERISA preemption, such as the pregnancy law at issue in Shaw, which " "mandated employee benefit structures or their administration" $" 83$ and thus had a connection with ERISA plans. ${ }^{.4}$

In De Buono v. NYSA-ILA Medical \& Clinical Services Fund, trustees of a fund established to administer an employee welfare benefit plan challenged a New York state tax on gross receipts of health care facilities. ${ }^{85}$ Because the fund operated its own nedical centers that were subject to the tax, the trustees argned that the tax was preempted by ERISA. The Court, relying heavily on both Travelers and Dillingham, held that the tax was not preempted. ${ }^{86}$ It rejected the Second Circuit's ruling in part because the lower court "fail[ed] to give proper weight to Travelers' rejection of a strictly hiteral reading of $\S 514(\mathrm{a}) .{ }^{\$ 87}$ Relying once again on congressional intent, the Court points out: "There is nothing in the operation of the [state law at issue] that convinces us it is the type of state law that Congress intended ERISA to supersede." ${ }^{.88}$

As in Travelers and Dillingham, the De Buono Court once again refused to overrule earlier ERISA preemption cases, instead distinguishing them from the current case in their more direct relationship to ERISA plans. Thus, in 1997, the Court reinforced its position, holding that the Travelers preemption analysis is appropriate when a law does not clearly make reference to an ERISA plan. But the Court has taken this new direction without overruling its earlier case law, leaving ERISA preemption in a questionable state.

II

ERISA PREEMPTION of SAN Francisco's Equal BeneftTs Ordinance

\section{A. Background on San Francisco's Equal Benefits Ordinance}

\section{History and Effect of the Ordinance}

In late 1996, the San Francisco Board of Supervisors unanimously approved and Mayor Willie Brown signed into law a revolutionary municipal ordinance. ${ }^{89}$ Although it did not take effect until June 1, 1997,

83. Id. at 327 (quoting Travelers, 514 U.S. at 658).

84. See id. at 328.

85. 520 U.S. 806 (1997).

86. The Court reasoned:

A consideration of the actual operation of the state statute leads us to the conclusion that [it] is one of 'myriad state laws' of general applicability that impose some burdens on the administration of ERISA plans but nevertheless do not 'relate to' them within the mcaning of the governing statute.

Id. at 815 (citing Travelers, 514 U.S. at 668; Dillingham, 519 U.S. at 333-34).

87. Id. at 812-13.

88. Id. at 814 .

89. John King, Boardwatch, S.F. CHRON., Oct. 29, 1996, at A12 (recording that the Nondiscrimination in Contracts amendment to Administrative Code Chapter 12B was approved by a 
the Equal Benefits Ordinance aroused instant curiosity and controversy..$^{90}$ While many cities, including San Francisco, had already passed laws establishing domestic partnership registries or providing doinestic partner benefits to city employees, ${ }^{11}$ the Equal Benefits Ordinance goes one step further. It requires that all companies contracting with the City provide benefits to the domestic partners of their employees equal to those provided to spouses of employees. ${ }^{92}$

In essence, the Ordinance prevents San Francisco from contracting with companies that do not give equal benefits to domestic partners of employees. ${ }^{93}$ The Ordinance forbids city contractors from discriminating "in

9-0 margin, with two abstentions, on October 28, 1996); see also San Francisco Requires Domestic Partner Benefits for City Contractor Employees, West's Legal News, Nov. 29, 1996, available at 1996 WL 683108 [hereinafter San Francisco Requires Domestic Partner Benefits].

90. The San Francisco Ordinance was the first of its kind to attempt to change the employee benefit policies of the private sector. Because almost 8,000 businesses compete for $\$ 1$ billion a year in contracts with the City, see San Francisco Requires Domestic Partner Benefits, supra note 89, the Ordinance's effects are much broader than previous laws. While many have praised the Ordinance's extension of nondiscrimination principles into the realm of employee benefits, several challenges to the new law appeared even before its effective date. The Roman Catholic Archdiocese of San Francisco, whose service organization, Catholic Charities, holds a City contract, stated it was unwilling to comply with the Ordimance's requirements because of religious beliefs. See Mark W. Davis, Rule of Law: Catholic Church Resists San Francisco's Gay Agenda, WALL St. J., Feb. 5, 1997, at A19; SlindFlor, supra note 12. Members of the Board of Supervisors were able to compromise with the Church by allowing it to apply its nonspousal benefits to any household member, instead of to a domestic partner denoted as such. See Price, supra note 12.

Other companies initially refused to comply with the Ordmance, but the Board of Supervisors and San Francisco's Human Rights Commission, the city organization charged with implementing the Ordinance, have been unwilling to waive the compliance requirements for any business, giving them the option to litigate or not to contract with San Francisco. See Price, supra note 12 (quoting Supervisor Tom Ammiano as saying: "Everybody has the option to litigate against us or to take a walk. Those options are real."). Most have either complied or no longer do business with the City. The Salvation Army, for instance, no longer receives City funds for its programs serving the homeless, drug addicts and the aged because it was unwilling to comply with the Ordinance on religious grounds. See Rachel Gordon \& Tyche Hendricks, Salvation Army Snubs S.F., S.F. ExAMINER, June 4, 1998, at Al. Other contractors have filled that service role and currently receive those funds, but the Salvation Army's operations in San Francisco have been cut back due to the Ordmance. See id.; Rachel Gordon, City's Senior Lunch Program Changes Hands; Salvation Army's Retreat Places Open Hand in Charge of Meals, S.F. ExAMINER, Aug. 8, 1998, at A3.

91. Berkeley, California, was the first municipality to provide domestic partner benefits to its city employees in 1982. Lambda Legal Def. \& Educ. Fund, States \& Municipalities Offering Domestic Partnership Benefits \& Registries, at http//:www.lambdalegal.org/ cgi-bin/pages/docuntents/record?record=403 (Nov. 22, 2000) (listing municipalities and states that provide benefits for domestic partners). Many cities followed, including San Francisco, which already had a long-standing domestic partner policy for city employees, as well as a domestic partner registry, before it passed the Ordinance. See Mary Ellen Podmolik, Airlines Sue S.F. Over Partner Law, Сн. Sun-Times, May 15, 1997, at 47.

92. S.F., CaL., AdmIN. Code § 12B.1.

93. Certain narrow exceptions to the Ordinance do exist. If the cost of providing domestic partner benefits exceeds that of providing spousal benefits, or vice versa, the contractor may require the employee to pay the excess costs. S.F., CAL., ADMN. CoDE $\S 12 \mathrm{~B} .1$ (b). Further, if a "contractor is unable to provide a certam benefit, despite taking reasonable measures to do so, the contractor shall not be deemed to discriminate in the provision of benefits if the contractor provides the employee with a 
the provision of bereavement leave, family medical leave, health benefits, membership or membership discounts, moving expenses, pension and retirement benefits or travel benefits [as well as any other benefits] ... between employees with domestic partners and employees with spouses, and/or between the domestic partners and spouses of such employees. $" 94$

The Ordinance acts as an explicit limitation on the City itself, not on private companies. Its language is directed at the ability of the City to contract with companies:

No contracting agency of the City, or any department thereof, acting for or on behalf of the City and County, shall execute or aniend any contract or property contract with any contractor that discriminates in the provision of [any benefits] between employees with doinestic partners and employees with spouses ....95

cash equivalent." Id. Thus, the Ordinance provides for exceptions in the event that certain companies (especially small companies with few options) are unable to find insurance that will cover domestic partner benefits. Id. Soine controversy has arisen as to what it means to have taken "reasonable measures" to provide domestic partner benefits, such as obtaining an insurance plan that will cover doinestic partmers. See Rachel Gordon, Detailing Domestic Partner Benefits: Officials Work Out Wrinkles Before Law Takes Effect, S.F. ExAMINER, Mar. 1, 1997, at A5 ("But what is reasonable?... For example, how many insurance carriers would an employer have to contact to show that it had made a reasonable attempt to secure coverage?'). This was a more significant problen before the Ordinance was enacted than it is today. At the time of the Ordinance's enactment in June 1997, only 14 insurance companies offered plans that provided donestic partner benefits. Less than a year later, over 100 insurance companies offered such plans. See Carla Mariuucci, S.F.'s New Partners Law Called Rousing Success, S.F. CHRoN., Jan. 7, 1998, at A13. This exponential growth in the number of insurance companies offering domestic partnership plans may be one of the crowning achievements of the Ordinance. See id.

94. S.F., CAL., AdMMN. Code § 12B.1(b).

95. Id. The Ordinance defines "contract" as

an agreement for public works or improvenents to be performed, or for goods or services to be purchased or grants to be provided, at the expense of the City and County or to be paid out of moneys deposited in the treasury or out of trust moneys under the control or collected by the City and County, and does not include property contracts, agreements entered into after June 1, 1997 pursuant to settlement of legal proceedings, contracts for urgent litigation expenses, or contracts for a cumulative amount of $\$ 5,000$ or less per vendor in each fiscal year.

Id. $\S 12 \mathrm{~B} .1(\mathrm{c})$.

"Contractor" is defined as "any person or persons, firm, partmership, corporation, or conbination thereof, who enters into a contract or property contract with a department head or officer empowered by law to enter into contracts of property contracts on the part of the City and County." Id.

The Ordinance defines a "property contract" as

a written agreement for the exclusive use or occupancy of real property for a term exceeding 29 days in any calendar year, whether by singular or cumulative instrument, (i) for the operation or use by others of real property owned or controlled by the City for the operation of a business, social, or other establishment or organization, mcluding leases, concessions, franchises and casements, or (ii) for the City's use or occupancy of real property owned by others....

Id. 
Thus, San Francisco only requires companies to provide domestic partner benefits when and if they choose to contract with the City. ${ }^{96}$

The Ordinance only applies to contracts entered into by the City after its effective date, June 1, 1997. Therefore, businesses need not comply until they enter a new contract with the City or renew an old one. United Airlines held a lease at SFO that expired in 1997, requiring them to enter into contract negotiations with the City for a new twenty-five year lease under the new policy. ${ }^{97}$ Because United refused to include the nondiscrimination provision in its new lease contract without investigating the effect such a policy would have on its nationwide operations, ${ }^{98}$ the City entered into a two-year lease with United, with an option to enter into a twenty-three year lease if it mcluded the provision to provide domestic partner benefits. ${ }^{9}$ After entering into the two-year lease, Umited determined it did not wish to comply with the Ordinance. Instead, represented by ATA, the airline filed suit in federal court, challenging the Ordinance. ${ }^{100}$ Similarly, Federal Express sought to lease a new cargo facility being built at SFO. ${ }^{101}$ Unwilling to enter a lease under the City's new terms, Federal Express chose to join ATA's suit against the City. ${ }^{102}$

\section{Legal Challenge to the Ordinance by the Air Transport Association}

On May 13, 1997, in Air Transport Ass'n of America v. City of San Francisco, the Air Transport Association of America, representing United and other SFO carriers and joined by Federal Express, filed suit in federal district court in Oakland against the City and County of San Francisco, the S.F. Human Rights Commission, and the S.F. Airport Commission. ${ }^{103}$ The plaintiffs challenged the Ordinance's validity on many grounds. First, they argued that San Francisco does not have the power to pass this sort of ordinance under its City Charter, the California Constitution, and the United

96. For more on this issue, see infra note 105 and accompanying text. For a brief explanation of Dormant Commerce Clause doctrine and its effect on the Ordinance, see infra note 107.

97. See Price, supra note 12.

98. See Rachel Gordon, Pact Nearer On Partners Law: City Gives United Airlines More Time to Comply with Domestic Pair Issue, S.F. ExAMINER, Feb. 3, 1997, at A5.

99. Podmolik, supra note 91; Price, supra note 12.

100. Podmolik, supra note 91 .

101. See Maria L. La Ganga \& Stephanie Simon, Judge Backs S.F. Law on Partners' Benefits, L.A. Times, Apr. 11, 1998, at A18.

102. See Air Transp. Ass'n of Am. v. City of San Francisco, 992 F. Supp. 1149, 1156 (N.D. Cal. 1998) (explaining that Federal Express joined the suit as a plaintiff but did not join the motions addressed in the order). See Rachel Gordon, Fed Ex to Get New SFO Lease Despite Domestic Partner Suit, S.F. ExAminer, Feb. 4, 1999, at A6. Two other companies, one represented by Pat Robertson's conservative American Center for Law and Justice, have sued the City as well. See S.D. Myers, Inc. v. City of San Francisco, No. C97-04463CW, 1999 U.S. Dist. LEX1S 8748 (N.D. Cal. May 27, 1999) (denying S.D. Myers' motion for summary judgment and holding that S.D. Myers lacks standing on its ERISA preemption claim); PM\&M Elec., Inc. v. City of San Francisco, No. C97-02250-CW (N.D. Cal. filed June 17, 1997) (voluntarily dismissed by stipulation May 26, 1998).

103. ATA, 992 F. Supp. 1149. 
States Constitution. Second, ATA argued that the Ordinance was preempted by federal law, namely ERISA, the Airline Deregulation Act (ADA), and the Railway Labor Act (RLA). ${ }^{104}$

The City defended the Ordinance as valid local law-making. Even if the Ordinance was invalid for constitutional or preemption reasons, the City argued, it was protected by the market participant exception. The market participant exception is a judicially created doctrine providing that when a municipahty or state is acting as a market participant (such as when a city contracts for a certain good or service) instead of as a regulator, it may take actions that would otherwise be impermissible. ${ }^{105}$ The Ordinance regulates the City itself, disallowing it from entering into contracts with companies that do not show compliance. By structuring the Ordinance as a limitation on the City itself, San Francisco may be able to require those with whom it does business to provide domestic partner benefits under the market participant exception, even though it could not regulate broadly in the same way. The City Attorney argued that San Francisco, as any market participant, could require anything it liked of the companies with which it did busmess.

The court, in a decision by Judge Claudia Wilken, dismissed the plaintiffs' objections to the Ordinance on the basis of the S.F. City Charter, the California Constitution, and preemption by the RLA. ${ }^{106}$ Absent these claims, ATA argued that the Ordinance is imvalid on two major grounds. First, the plaimtiffs argued that the Ordinance is unconstitutional because it affects interstate commerce in violation of the Dormant Commerce Clause. The Dormant Commerce Clause doctrine is implicated when a state or

104. See Airline Deregulation Act, 49 U.S.C. § 41,713(b) (1994); Railway Labor Act, 45 U.S.C. § 151 (1994).

105. For instance, in Hughes v. Alexandria Scrap Corp., 426 U.S. 794 (1976), Maryland purchased crushed auto hulks from in-state sellers at an above-market price in order to rid the state of abandoned cars. The Supreme Court held that Maryland did not violate the Commerce Clause because it was acting as a market participant in favoring its own citizens. The market participant exception often arises in Donnant Commerce Clause cases, such as Reeves, Inc. v. Stake, 447 U.S. 429 (1980), where a state-owned cement plant favored in-state custoners in times of shortage. The Court im Reeves held that states do not violate the Dornant Commerce Clause when they act as proprietors. There are some cases in which simply acting as a market participant cannot save a state action from unconstitutionality. In South-Central Timber Development, Inc. v. Wunnicke, 467 U.S. 82 (1984), the Court held the market participant exception inapplicable to an Alaska requirement that timber sold by the state at preferential prices be processed within the state, in part because Alaska was attempting to affect parties beyond those with whoin it was contracting.

106. $A T A, 992 \mathrm{~F}$. Supp at 1159-60, 1180-91. The decision left the issue of preemption by the ADA for a later ruling upon further examination. See id. at 1188 (finding plaintiffs may prevail on ADA preemption claims if they show that the Ordinance "creates coercive economic incentives for air carriers to alter their routes"). After a hearing on the inatter, the court ruled that the Ordinance is not preempted by the ADA. Air Transport Ass'n of Am. v. City of San Francisco, No. C 97-01763 CW, 1999 U.S. Dist. LEXIS 8747 (N.D. Cal. May 27, 1999). The plaintiffs are currently challenging this ruling in the Ninth Circuit Court of Appeals. See Bob Egelko, Airlines Renew Attack on S.F. Domestic Partner Ordinance, Say City's Measure Violates Federal Law, S.F. Examiner, Nov, 15, 2000, at A6. 
local government passes a law that has an effect on interstate commerce, in an area that Congress has not chosen to regulate. ${ }^{107}$ Here, ATA claimed that San Francisco could not require a company it contracts with to adopt doinestic partner benefits for all of its einployees nationwide, even those whose work does not relate to San Francisco in any way, since this would have an impermissible effect on interstate commerce. ${ }^{108}$ The court agreed, holding that the Ordinance is invalid because the City was not a mere market participant when it attempted to regulate out-of-state conduct unrelated to City contracts. ${ }^{109}$ The $A T A$ court also held that the Ordinance unconstitutionally violated the Dormant Commerce Clause to the extent that it applied to out-of-state contracts that are unrelated to the purposes of a City contract. ${ }^{110}$ San Francisco was attempting to regulate the actions of companies nationwide, and could not be protected by the market participant exception.

Second, the plaintiffs claimed that the Ordinance was preeinpted by ERISA. The court held that the market participant exception protects the Ordinance from ERISA preemption when the City is acting as a market participant, such as when it buys goods and services as any proprietor may. ${ }^{111}$ But at the airport, the City holds a monopoly and acts more as a regulator than as a market participant, and so cannot claim a market participant defense against claims by airport occupants such as Umited and Federal Express. ${ }^{112}$ Thus, the validity of a major portion of the Ordinance rested on the crucial question of ERISA preemption. As will be explained in more detail below, the court held that ERISA does preempt the Ordinance, and San Francisco cannot force airlines at SFO to provide health and other ERISA-covered benefits to their employees.

\section{Implications of the Dispute for Other Local Governments}

It may appear at first that the court's decision in $A T A$ as to whether ERISA preempts the Ordinance is fairly unimportant. It affects only a narrow group of cases, such as those arising from contracts at SFO, where

107. Congress has the ability to regulate interstate commerce under the Constitution. U.S. CoNST. art. I, $\S 8, \mathrm{cl}$. 3. The Dormant Commerce Clause doctrine provides that this grant of power to Congress hinders the ability of states to legislate in areas that may affect interstate commerce, when Congress has not yet legislated in that area. Congressional silence, under Dormant Commerce Clause doctrine, may prcempt state actions that discriminate against interstate commerce. See, e.g., West Lynn Creamery, Inc. v. Healy, 512 U.S. 186 (1994) (invalidating a Massachusetts law, which favored in-state dairy farmers, because the negative aspect of the Commerce Clause limits the power of the states to adopt regulations that discrimmate against interstate commerce).

108. $A T A, 992$ F. Supp. at 1155.

109. Id. at 1160-65. See supra note 105 and accompanying text for an explanation of the market participant exception.

110. Id.

111. See id. at 1180 .

112. See id. 
the City acts as a regulator and is not protected by the market participant exception. Further, because United eventually decided to voluntarily offer its employees domestic partner benefits, imcluding ERISA-covered benefits such as health care for same-sex domestic partners, ${ }^{113}$ the effect of ERISA on the Ordinance appears negligible in practical terms.

But it is important to place this case in the larger context of local efforts to pass similar domestic partner ordinances as well as other antidiscrimination laws. San Francisco's Ordinance was the first of its kind, but it is rapidly being duplicated by other cities. Seattle and Los Angeles have already followed San Francisco's lead and enacted similar ordinances requiring city contractors to provide domestic partner benefits to their employees. ${ }^{114}$ But as radical and far-reaching as these types of ordinances may seem, they only affect a small group of employers who choose to contract with cities. For instance, the San Francisco Ordinance only applies to compamies that contract with the City in some way, affecting only some 8,000 employers; ${ }^{115}$ it is not a law of general application that affects every company in the City and County of San Francisco.

Most probably, the S.F. Board of Supervisors would have liked to pass a more widely applicable ordinance that would require all City employers to provide domestic partner benefits. But they were probably aware that they would have run into legal problems, sucli as ERISA preemption, that could not be avoided unless they framed the Ordinance as an instance of market participation. Thus, the Ordinance is worded to limit the City itself when it contracts with others, allowing companies to avoid the Ordinance's requirements by simply not contracting with the City. ${ }^{116}$

Let us assume that a city desired to pass an ordinance that applied to all employers within its boundaries, requiring them to provide domestic partner benefits, whether or not they contracted with the city itself. In sucl a case, the question addressed by the court in $A T A$, whether the ordinance is preempted by ERISA absent the market participant exception, becomes crucial. Preemption severely limits local governments' ability to pass

113. Edward Epstein, United Airlines Capitulates on Partners Issue; Full Benefits Worldwide for Gay, Lesbian Couples, S.F. CHRON., July 31, 1999, at A1. United's new benefit package provides full ERISA and non-ERISA benefits to the same-sex domestic partners of its employees, but only nonERISA benefits to the opposite-sex domestic partners of its employees.

114. See J. Martin McOmber, Benefits for Gay Couples Approved by City Council, SEATME Tmies, Nov. 23, 1999, at B3; Rick Otlov, Council Extends Partners' Benefits to Contractors, L.A. DAILY News, Nov. 18, 1999, at N1.

115. See San Francisco Requires Domestic Partner Benefits, supra note 89.

116. The wording and effect of many laws have been changed out of concern for ERISA preemption. For example, in 1989 the Seattle City Attorney initially announced that a Human Rights Department ruling extending health benefits to unmarried partners of city employees applied to all private einployers in the city. Later, the City Attorney reversed his opinion, saying that ERISA would exempt private employers from such a ruling. Kevin Gudridge, Seattle Suspends Live-In Health Benefit Rule, NAT'L UNDERWRITER, June 5, 1989, at 5. 
antidiscrimination laws that protect their citizens, as the Ordinance does. With this in mind, we will turn to the issue of ERISA preemption.

\section{A. ATA's ERISA Preemption Holding}

The district court's decision in ATA relied on several theories of law, but the most crucial was its ERISA preemption decision, which determined whether the City could in fact require companies leasing land at SFO to provide certain benefits to domestic partners of their employees. The court in $A T A$ held that, at least at the airport, ${ }^{117}$ the Ordinance is preempted by ERISA as applied to benefits covered by ERISA and provided through ERISA plans, such as family medical and bereavement leave paid from accumulated funds, and health and pension benefits. ${ }^{118}$ The Ordinance is not preeinpted with respect to benefits that are not covered by the Act, such as inoving expenses, membership and membership discounts, and travel benefits. ${ }^{119}$ Nor is it preempted with respect to ERISA-covered benefits offered through non-ERISA plans, such as family medical and bereavement leave paid out of general assets. ${ }^{120}$ Thus, companies like Umited and Federal Express must provide some benefits to domestic partners (constituting a partial victory for the Ordinance), but they need not provide ERISA benefits provided through ERISA plans-most importantly, this includes health and pension benefits.

The court in $A T A$ recognized that the Supreme Court had retreated from its expansive interpretation of section 514(a), and walked through a step-by-step preemption analysis considering the influence of Travelers and its progeny. ${ }^{121}$

As in Shaw, Travelers and Dillingham, the court broke down its ERISA analysis into two parts, looking at whether the Ordinance has a "reference to" or a "connection with" ERISA plans. ${ }^{122}$ Judge Wilken

117. The court's decision relies on the fact that the City exercises more power than an ordinary consumer at the airport, and thus is not shielded as a market participant from ERISA preemption as to companies that lease land at SFO. ATA, $992 \mathrm{~F}$. Supp. at 1176-80. ATA does not answer the question whether the Ordinance is wholly valid as to other city contractors, but suggests that the determination must be made on a case-by-case basis, dependent on the monopoly power held by the City in the particular industry in question. See id. at 1180, 1191.

118. Id. at 1180 .

119. Id.

120. Id. ERISA-covered benefits are those benefits that ERISA explicitly addresses, namely health care and pension plans. ERISA plans refer to any employee plans that require an ongoing administrative program that systematically pays certain benefits. Judge Wilken concluded that moving expenses are the only type of benefit listed in the Ordinance that does not require an ongoing administrative program, but that bereavement leave and family medical leave, if paid for through general assets, would therefore be offered through non-ERISA plans. Id. at 1169-75.

121. The court in $A T A$ also examined a possible market participant exception to ERISA preemption, but found, as in the Dormant Commeree Clause analysis, that the City is acting with too much power to be considered a mere proprietor at SFO (though the market participant exception could protect the City from ERISA preemption im other contexts). Id. at 1180.

122. Id. at 1166 . 
recognized the importance of the two-part inquiry in Travelers and Dillingham. "If a law refers to ERISA plans, it is automatically preempted, but if the law does not refer to ERISA plans, courts must consider, under the 'connection with' test, whether the purpose and effect of the law interfere with Congress's objectives in enacting ERISA."123

After dismissmg several objections to ERISA preemption made by the City, ${ }^{124}$ the court examined the "reference to" inquiry. It followed Dillingham's understanding that "a law refers to an ERISA plan if it 'acts immediately and exclusively upon ERISA plans ... or [if] the existence of ERISA plans is essential to the law's operation."'125 The court pointed out that some of the benefits described in the Ordinance, such as membership or membership discounts, moving expenses and travel benefits, are not ERISA-covered benefits. ${ }^{126}$ Judge Wilken held that as to these non-ERISA benefits, the Ordinance is not preempted. ${ }^{127}$ Further, because the existence of ERISA plans is not essential to the Ordinance's operation, and because the Ordinance does not act exclusively on ERISA plans, the Ordinance does not make "reference to" ERISA plans. ${ }^{128}$

The court then examined whether the Ordinance has a "connection with" ERISA plans under the Travelers formulation, focusing on "Congress" objectives in enacting ERISA."129 Judge Wilken found that Congress had two purposes in enacting ERISA: protecting plan

123. Id. at 1175.

124. The City argued that the Ordinance does not relate to ERISA plans for four reasons, three of which the court rejected. First, the City argued that the Ordinance refers only to benefits, not plans. Judge Wilken found that all of the benefits listed in the Ordinance, except for moving expenses, can only be administered through some sort of plan. Further, the Ordinance defines "benefits" as "any plan, program or policy. ..." Thus, the Ordinance refers to plans, not just benefits. Id. at 1168-69.

Second, the City claimed that the Ordinance does not mandate changes in ERISA plans because enployers can provide separate plans to provide benefits for domestic partners and those separate plans would not be ERISA plans. This argument was rejected because such stand-alone plans would still be an employee welfare benefit plan under ERISA, and further, such plans would be "measured by reference to" ERISA plans, which was found to relate to ERISA plans in District of Columbia v. Greater Washington Board of Trade. ATA, 992 F. Supp. at 1169-73.

Third, the City argued that the Ordinance does not operate exclusively on ERISA plans, which the court agreed with in its "reference to" analysis. Id. at 1173-75.

Fourth, the City argued the Ordinance does not have a substantial connection with ERISA plans because it creates only indirect economic incentives for employers to modify their plans. The court, recoguizing this argument as reflecting the fact that the Ordinance only applies to city contractors, addressed this issue in its market participant analysis, wherein it held that the City "exerts more economic power at the Airport than an ordinary consumer would," and was therefore not shielded from ERISA preemption. Id. at 1180 .

125. Id. at 1168 (quoting Cal. Div. of Labor Standards Enforcement v. Dillingham Constr., N.A., 519 U.S. 316,329 (1997)).

126. Id. at 1173-74.

127. Id. at 1174 ("To the extent the Ordinance requires provision of non-ERISA benefits, it is not preempted by ERISA. This holds true even if these non-ERISA benefits are administered through a plan that also provides ERISA benefits.").

128. Id. at 1175.

129. Id. at 1176. 
participants and beneficiaries from mismanagement of benefits funds, and easing the administrative burden on employers by eliminating the need to comply with inconsistent state and local regulations. ${ }^{130}$ The court, while recognizing that the Ordinance's goal of combating sexual orientation discrimination was a "laudable" one, found that the Ordinance "directly interferes with ERISA's goal of shielding employee benefit plans from imconsistent State and local regulation."131

Most damaging, the court in ATA found that the Ordinance in effect "require[s] City contractors with discriminatory benefit plans to modify those plans."132 Comparing the Ordinance's effect to the law at issue in Shaw, Judge Wilken held that the Ordinance "mandates employee benefit structures" $" 133$ by requiring City contractors to provide benefits to domestic partners on a nondiscriminatory basis. Although recent ERISA cases, exemplified by Travelers, have applied a more critical approach to ERISA preemption, they did not overrule the holding in Shaw that laws that "'mandate employee benefit structure or their administration' are preempted under the 'counection with' test." 134 Instead, recent cases have distinguished themselves from laws like the New York Human Rights Law at issue im Shaw, which related to ERISA plans directly and substantially by requiring employers to provide certam benefits (pregnancy benefits) in a nondiscriminatory manner. ${ }^{135}$

Thus, ATA falls into the category of cases like Shaw, that were not saved from preeinption by Travelers and its progeny. Instead, such laws were used as examples of areas that ERISA still preempts, $m$ contrast to the laws upheld by the Supreme Court in recent years. Although the court in $A T A$ gave the Supreme Court's recent approach to ERISA preemption due weight in its analysis, it nevertheless found San Francisco's Ordinance preempted by ERISA in important respects, allowing companies like Umited and Federal Express to continue their policies of not providing equivalent health and other ERISA benefits to the domestic partners of their employees.

It may appear that, with the Suprene Court's new, inore commonsense approach to ERISA preemption since Travelers, courts should find

130. Id.

131. Id.

132. Id.

133. Id. (quoting N.Y. State Conference of Blue Cross \& Blue Shield Plans v. Travelers Ins. Co., 514 U.S. 645,658 (1995)).

134. Id.

135. See Travelers, 514 U.S. at 658 (distinguishing Shaw, FMC Corp. v. Holliday, and Alessi v. Raybestos-Manhattan, Inc. by noting that "[i]n each of these cases, ERISA pre-enpted state laws that mandated employee benefit structures or their administration.... Both the purpose and the effects of the New York surcharge statutes distinguish them."); Cal. Div. of Labor Standards Enforcement v. Dillingham Constr., N.A., 519 U.S. 316, 327, 332 (1997) (quoting Travelers, 514 U.S. at 658, above, and pointing out that the law at issue "does not bind ERISA plans to anything"). 
San Francisco's Ordinance not preempted by ERISA. Three of the past four decisions by the Supreme Court have upheld state laws against ERISA preemption challenges. ${ }^{136}$ Also, the Ordinance does not directly affect any of the plan management issues that ERISA covers, like reporting, disclosure, and fiduciary responsibilities. ERISA does not address who may or should be covered by an employee benefit plan, which is what the Ordinance addresses. Moreover, as will be addressed in nore detail later, the Ordinance regulates in an area traditionally left to the states: the employment relationship. Therefore, under the more traditional preemption analysis that Travelers proposes, one may be encouraged to argue that the Ordinance and others like it are not preempted by ERISA.

But in fact, under current Supreme Court analysis of ERISA preemption, San Francisco's Ordinance, and laws like it, are preempted. ${ }^{137}$ Judge Wilken gave the Ordinance as generous a reading as is possible under current ERISA preemption doctrine. But still, she found the Ordinance preempted in important respects. Even accounting for the Supreme Court's recent move toward a inore narrow understanding of ERISA preemption, the Ordinance has a "connection with" and thus "relates to" employee benefit plans. As the court in $A T A$ pointed out, the Ordinance, "like the nondiscrimination law that the Supreme Court found preempted in Shaw, 'mandates employee benefit structures' because it requires City contractors to provide the benefits on a nondiscriminatory basis."138

Because the Court in Travelers and Dillingham refused to explicitly overrule its earlier ERISA holdings but instead distinguished them, ${ }^{139}$ the authority of those earlier cases is still good law. This was crucial in ATA, for Judge Wilken compared the Ordinance to the law in Shaw as a reason for finding the Ordinance preempted. As long as cases like Shaw, FMC and Alessi are still good Supreme Court authority, municipal ordinances like

136. See Boggs v. Boggs, 520 U.S. 833 (1997) (holding Louisiana community property law preempted by ERISA under traditional conflict preemption principles); De Buono v. NYSA-ILA Med. \& Clinical Servs. Fund, 520 U.S. 806 (1997) (upholding New York tax on gross receipts of health care facihties); Dillingham, 519 U.S. 316 (upholding California prevailing wage law); Travelers, 514 U.S. 645 (upholding New York surcharge statutes).

137. A recent Hawaii state law had similar effects as the Ordinance, providing for certain benefits for "reciprocal beneficiaries." Haw. REV. STAT. ANN. § 572C (Michie, WESTLAW through 1999 Reg. Sess.). Its passage coincided with Hawaii's brush with same-sex marriage, and was evidently an attempt to diffuse the effort to legalize same-sex marriage. The law's most important provision, health coverage for the partners of private employees, was struck down in late 1997. U.S. District Judge David Ezra, in an unreported decision, found that the law was preempted by ERISA, just as Judge Wilken did in ATA. See Susan Essoyan, Hawaii Finds Slow Response to Domestic Partners Law, Dallas Morning News, Dec. 28, 1997, at 5A.

138. $A T A, 992$ F. Supp. at 1176.

139. Travelers, 514 U.S. at 657-58; Dillingham, 519 U.S. at 330. 
San Francisco's that require employers to provide benefits on a nondiscriminatory basis are plainly preempted by ERISA. ${ }^{140}$

\section{Necessity of Rescuing San Francisco's Equal Benefits Ordinance from ERISA Preemption}

San Francisco enacted its Equal Benefits Ordinance because it did not wish to support businesses that discriminated in the provision of einployee benefits on the basis of sexual orientation or marital status. In so doing, San Francisco's Board of Supervisors was seeking to establish equality in the workplace for its citizens. ${ }^{141}$ As long as such a law does not clearly conflict with or impair the operation of federal law, ${ }^{142}$ it should be allowed to stand.

Prior to the passage of sweeping federal legislation such as the Fair Labor Standards Act and ERISA, the states traditionally regulated the employment relationship. ${ }^{143}$ State and local governments have often been at the forefront in regulating the employment relationship, passing progressive legislation to protect employees. ${ }^{144}$ State antidiscrimination laws existed before the enactment of Title VII of the Civil Rights Act of 1964, and even now many states prohibit discrimination in areas not yet covered by federal law, such as sexual orientation and marital status discrimination. ${ }^{145}$ Thus, local and state laws protecting employees against

140. For an extensive analysis of whether San Francisco's ordinance is preempted by ERISA after Travelers, see Jeffrey A. Brauch, Municipal Activism v. Federal Law: Why ERISA Preempts San Francisco-Style Domestic Partner Ordinances, 28 Seron HaLl L. REv. 925 (1998) (arguing that the Ordinance is preempted by ERISA, even after Travelers).

141. See Rachel Gordon \& Anastasia Hendrix, City Celebrates Anniversary of Partners' Law: More Than 1,700 Companies Provide Equal Benefits, S.F. EXAMINER, June 2, 1998, at Al (quoting Supervisor Leslie Katz as calling the Ordinance an effort to establish "equality in the workplace").

142. There is an assumption, where a federal law is claimed to preempt state action in a field of traditional state regulation, "'that the historic police powers of the States were not to be superseded by the Federal Act unless that was the clear and manifest purpose of Congress." Travelers, 514 U.S. at 655 (quoting Rice v. Santa Fe Elevator Corp., 331 U.S. 218, 230 (1947)).

143. See Henry H. Drummonds, The Sister Sovereign States: Preemption and the Second Twentieth Century Revolution in the Law of the American Workplace, 62 FoRdHAM L. REv. 469, 49091 (1993) (citing numerous ways in which state law played a leading role in regulating the employment relationship to protect employees and in leading the "imdividual rights revolution").

144. See id.

145. States that prohibit sexual orientation discrimination in some form include Califorma, $C_{A L}$. Gov'T CoDE \& 12,920 (West, WESTLAW through 1999 portion of 1999 Legis. Sess. and Ist Ex. Sess.); Connecticut, ConN. Gen. Stat. ANN. § 46a-81c (West, WESTLAW through 1999 legislation); Hawaii, Haw. Rev. Stat. AnN. § 378-2 (Michie, WESTlAW through 1999 Reg. Sess.); Massachusetts, MAss. GEN. LAWS ANN. ch. 151B, $\S 4$ (West, WESTLAW through c.102 of 2000 2d Sess.); Minnesota, Minn. Stat. AnN. $\$ 363.03$ (West, WESTLAW through 1999 Reg. Sess.); New Jersey, N.J. Stat. ANN. \$ 10:5-12 (West, WESTLAW through c. 441 of 1999 Sess.); Rhode Island, R.I. GEN. LAws § 28-5-7 (WESTLAW through 1999 Reg. Sess.); Vermont, Vt. Stat. ANN. tit. 21, § 495 (WESTLAW through 2000 Reg. Sess.); and Wisconsin, Wis. STAT. $\$ 111.36(1)$ (b)-(d) (West, WESTLAW through 1999 act 75). The District of Columbia also prohibits sexual orientation discrimination. D.C. CoDE ANN. § 1-2512 (1998); see also Drummonds, supra note 143, at 500 (citing 
discrimination in the workplace are not unique, but are instead often the primary method by which nondiscrimination principles are introduced to protect newly recognized groups. Federal legislation often follows, once Congress acknowledges the importance and utility of extending protection to a particular subordinated group. ${ }^{146}$

Certain marginalized groups have had better luck attaining civil rights at the local or state level than in Congress because of the greater relative political power that can be wielded in local arenas. ${ }^{147}$ As one commentator points out, "the probability of the people, or their representatives, acting to prohibit [sexual orientation] discrimination at the state and local level often may exceed the probability of enacting such legislation at the federal level."148 This phenomenon is evidenced not only by the higher level of protection on the basis of sexual orientation in many states, ${ }^{149}$ but also by the number of municipalities that provide domestic partner benefits to their city employees, which is constantly increasing. ${ }^{150}$ Thus, many political activists "see state and local politics as bastions for innovative regulatory initiatives." $" 151$

sexual orientation and marital status discrimination as subjects currently only prohibited by various states). For articles addressing state enactment of antidiscrimination legislation, see generally Developments in the Law - Sexual Orientation and the Law, 102 HaRv. L. Rev. 1508 (1989) (discussing state laws prohibiting sexual orientation discrimination); Note, The Right to Equal Treatment: Administrative Enforcement of Antidiscrimination Legislation, 74 HaRV. L. REV. 526 (1961) (discussing the role of state antidiscrimination cominissions).

146. This was the case with the Americans with Disabilities Act of 1990 , 42 U.S.C. $\$ \$ 12,101$ 12,213 (1994), which was passed by Congress long after many states had determined disability to be a protected class under their state antidiscrimination statutes. See Drummonds, supra note 143, at 500 .

147. See, e.g., Drummonds, supra note 143, at 490-91, 500-01 (explaining that state law is often a leader in providing protection against discrimination in areas such as disabilities, sexual orientation, and marital status).

148. Id. at 501 .

149. See supra note 145.

150. Over 100 municipalities currently have ordinances that prohibit sexual orientation discrimination. See Nan D. Hunter et al., The Rights of Lesbians and Gay Men: The Basic ACLU Gume to a Gay Person's Rights 204-08 (3d ed. 1992) (listing municipalities that prohibit sexual orientation discrimination); see also Lambda Legal Def. \& Educ. Fund, supra note 86 (listing extent of domestic partner benefits provided by local municipalities).

151. Drummonds, supra note 143, at 515; see also David Morris, You Can Fight City Hall, UTNE READER, Nov./Dec. 1991, at 89 ("[L]ocal politics, unlike national politics, can truly be einpowering for everyday citizens."). For example, ERISA has been held not to preempt state laws that prevent discrimination on the basis of race and sex, because such laws reinforce and support Title VII. See, e.g., Shaw, 463 U.S. at 89, 103, 108-09; see also supra notes 46-50. But sexul orientation is not covered by Title VII. Title VII of the Civil Rights Act of $1964 \S 703,42$ U.S.C. $\$ \$ 2000 e-2$ (1994) (prohibiting employment discrimination on the basis of race, color, religion, sex, or national origin only). Accordingly, state laws prohibiting sexual orientation discrimination can be preenpted by ERISA without hindering the goals of Title VII. Thus, when states act progressively im defining new arcas of impermissible discrimination, ERISA's preemptive reach prevents such laws from having full effect, because they cannot influence employee benefit plans, and because the new areas of discrimination are not yet protected by another federal law. 
Further, the Court's current approach to ERISA preemption has recognized that when laws address issues traditionally within the police power of the states the assumption is that "Congress does not intend to supplant state law."'152 San Francisco's law, which attempts to regulate aspects of the employment relationship, falls directly within the realm of actions traditionally exercised by states, and should benefit from the presumption against preemption. ${ }^{153}$

Preemption by ERISA prevents local and state governments from protecting their citizens' imterests in the extremely important arena of employee benefits. Unfortunately, many well-meaning state laws prohibiting sexual orientation or marital status discrimination exempt discrimination im employee benefits from their coverage because of the threat of ERISA preemption. ${ }^{154}$ This is the case even though ERISA, in its coverage, does not address the question of who may or should be covered by einployee benefit plans. Thus, ERISA preemption currently impedes local and state governments in their efforts to secure benefits such as health care for their citizenry on a nondiscriminatory basis. As the following Part will illustrate, legislative and judicial error rather than preemptive intent may be the cause of such impediment.

III

Problems in Current ERISA Preemption Jurisprudence

\section{A. Legislative Error: The Irrationally Broad Scope of ERISA Preemption}

ERISA was designed to protect employee welfare and pension plan participants and beneficiaries by providing standards for plan administration, so as to avoid the mismanagement and depletion of pension plan

152. De Buono v. NYSA-ILA Medical and Clinical Services Fund, 520 U.S. 806, 814 (1997) (quoting N.Y. State Conference of Blue Cross \& Blue Shield Plans v. Travelers Ins. Co., 514 U.S. 645, 654 (1995)).

153. See Catherine L. Fisk, ERISA Preemption of State and Local Laws on Domestic Partnership and Sexual Orientation Discrimination in Employment, 8 UCLA WoMEN's L.J. 267, 286 (1998) ("The regulation of the terms of employment for the protection of employees are traditional exercises of police powers, as are the definition of marriage and of other family relationships.") (footnote omitted).

154. CAL. LAB. Code $§ 1102.1$ (Deering Supp. 1998), repealed by 1999 Cal. Legis. Serv. ch. 592 (West 1999) (retaining the prohibition on sexual orientation discrimination in housing and employment but moving it to CAL. Gov'T CODE $\$ 12,920$ ). To the extent that state fair einployment laws encompass equality in einployee benefits, ordinances like San Francisco's could become unnecessary, if prohibition of sexual orientation or marital status discrimination in employee benefits could be interpreted as requiring employers to provide domestic partner benefits. See, e.g., Univ. of Alaska v. Tumeo, 933 P.2d 1147 (Alaska 1997) (holding University's failure to provide domestic partner benefits to same-sex partners constituted discrimination on the basis of marital status) (overruled by amendment to state statute); Tanner v. Or. Health Sci. Univ., 68 Empl. Prac. Dec. (CCH) para. 44,211 (Or. Cir. Ct. 1996) (finding denial of benefits to same-sex partners violates state law and constitution; ordering state agency to provide benefits). 
funds. ${ }^{155}$ Congress accomplished this goal by providing for extensive reporting, disclosure, and fiduciary duty requirements. It then included in ERISA an expansive preemption clause, imtended to "round out the protection afforded participants by eliminating the threat of conflicting and inconsistent State and local regulation."156 Unfortunately, members of Congress failed to consider the effect such a broad preemption clause would have on the ability of states to regulate in fields even remotely related to employee benefit plans. ${ }^{157}$

Many commentators have criticized the broad language of ERISA's preemption clause because it effectively prevents state regulation in any area touching employee benefit plans, even though ERISA itself only chose to federally regulate a narrow aspect of benefit plan administration. Section 514(a), a last minute addition to the statute, "was not a deeply considered result of the years of planning, negotiation and drafting"158 that Congress put into the statute itself. This lack of attention has created numerous difficulties in interpreting and applying the all-encompassing language of ERISA's preenption clause. "[B]ecause the language of Section 514(a) emerged at the last minute without full consideration, neither the language, the legislative history, nor the context of its enactment supphies any real help in the task of determining what it means."159

As has been shown, courts have invalidated numerous state laws by interpreting section 514(a) broadly because its language encompasses all state laws that "relate to any employee benefit plan."160 Judges have done this, however, in the absence of clear congressional intent to preempt the field of employee benefits im such an expansive manner. "[N]either before nor after the enactinent of ERISA did Congress ... view preemption policy issues as settled in the way that the sweeping statutory language of section 514 might suggest." $" 161$

There is evidence in the legislative history that the bill's sponsors considered ERISA's preemption clause important to its operation; one representative called the clause "the crowning achievement of this legislation." 162 While those who enacted ERISA imtended it to have a strong preemptive effect im order to accomplish its goals, the sparse legislative history is not uniformly supportive of the breadth of the preemption clause that resulted. In fact, the original House and Senate bills

155. See supra note 29 and accompanying text.

156. 120 CoNG. Rec. H29,197 (1974) (statement of Rep. Dent).

157. See infra notes 158,159 , and 161 and accompanying text.

158. Daniel M. Fox \& Daniel C. Schaffer, Semi-Preemption in ERISA: Legislative Process and Health Policy, 7 AM. J. TAX PoL'Y 47, 48 (1988).

159. Jay Conison, ERISA and the Language of Preemption, 72 WASH. U. L.Q. 619, 622 (1994).

160. 29 U.S.C. $\$ 1144(a)$ (1994).

161. Leon E. Irish \& Harrison J. Cohen, ERISA Preemption: Judicial Flexibility and Statutory Rigidity, 19 U. MiCH. J.L. REFORM 109, 116 (1985).

162. 120 CoNG. REC. 29,197 (1974) (statement of Rep. Dent). 
contained much narrower preemption provisions. The House bill provided that ERISA would only preempt state laws "relat[ing] to the reporting and disclosure responsibilities, and fiduciary responsibility, of persons acting on behalf of any employee benefit plan ...."163 The Senate version provided for preemption of state laws "relat[ing] to the subject matters regulated by this Act ...." ${ }^{\text {"164 }}$ The Conference Committee replaced these more conservative versions with the current provision, thereby appearing to intentionally broaden the scope of preemption. Given the lack of congressional debate on the matter, ${ }^{165}$ however, the reasons for this expansion are largely unknown. One cannot conclude whether the earlier bills better illustrate Congress's actual intent, or whether well-considered reasons supported the much broader resulting provision.

Conceding that ERISA's legislative history is minimally helpful in determining the scope of section 514(a), it is nevertheless clear that Congress intended the clause to have a strong preemptive effect. ${ }^{166}$ Even so, courts have applied section 514(a) much more broadly than Congress could have imagined, and with deleterious effects. One commentator points out that "the reach of ERISA preemption exceeds its pohicy rationale."167 State laws in areas entirely separate from employee benefit plan administration, but which have some indirect effect on such plans, have generated extensive litigation. ${ }^{168}$ Courts have invalidated many laws whose purposes are consistent with ERISA, because they in some way "relate to" employee benefit plans. ${ }^{169}$

ERISA's preemptive scope has expanded far beyond its regulatory force, creating a "regulatory vacuum"170 in which Congress has not chosen to legislate, but state law nonetheless cannot operate. San Francisco attempted to fill that vacuum by requiring employers to provide employee benefits on a nondiscrimmatory basis, but the City was unable to do so be-

163. H.R. 2, 93d Cong. $s 7$ (1974).

164. H.R. $4200,93 \mathrm{~d}$ Cong. $s 8$ (1973).

165. There was evidence of some concern that the earlier drafts of section 514 would fail to protect ERISA from state laws aimed at avoiding its effects. 120 CoNG. Rec. 29,942 (1974) (statement of Sen. Javits); see also Irish \& Cohen, supra note 161, at 112-13. Nevertheless, because section 514 was a last minute addition to the statute, Congress's true intent is largely unknown and unknowable.

166. E.g., Laura H. Harsbbarger, Note, ERISA Preemption Meets the Age of Managed Care: Toward a Comprehensive Social Policy, 47 SYRAcuse L. Rev. 191, 215 (1996) ("That ERISA was meant to have a tremendous preemptive effect cannot be seriously disputed.").

167. Druminonds, supra note 143, at 477.

168. See, e.g., De Buono v. NYSA-ILA Medical and Clinical Serviees Fund, 520 U.S. 806 (1997) (state tax on gross hospital receipts); Cal. Div. of Labor Standards Enforcement v. Dillingham Constr., N.A., 519 U.S. 316 (1997) (prevailing wage statute); N.Y. State Conference of Blue Cross \& Blue Shield Plans v. Travelers Ins. Co., 514 U.S. 645 (1995) (health care provider surcharge program).

169. See, e.g., District of Columbia v. Greater Washington Board of Trade, 506 U.S. 125 (1992); Shaw v. Delta Air Lines, Inc., 463 U.S. 85 (1983).

170. Irish \& Cohen, supra note 161, at 128 (quoting Gast v. State, 585 P.2d 12, 23 (Or. App. 1978)). 
cause of ERISA preemption. This problem is not unique to domestic partner ordinances; the Court invalidated the pregnancy discrimination laws at issue in Shaw, for example, because of ERISA. While the issue in Shaw is now solved by the imclusion of pregnancy discrimination in Title VII, laws like San Francisco's that seek to protect citizens froin sexual orientation and marital status discrimination are prime examples of the problems ERISA preemption creates. San Francisco illustrates one of the many ways in which ERISA preemption has unnecessarily hindered state and local regulation of the employment relationship. ${ }^{171}$ The inability of state and local lawmakers to pass laws that protect their citizens from discrimination in an area of traditional state concern such as employee benefits is a problein in dire need of a solution.

\section{B. Judicial Error: The Supreme Court's Mistakes}

While the greatest hurdle in avoiding ERISA preemption of state laws is the broad language used by Congress in section 514(a), the Supreme Court's precedent in the area is another major obstacle in freemg local regulation from federal preemption. Even after Travelers, laws like San Francisco's are not safe from preemption, for two mam reasons. First, while the Court claims to focus on congressional intent in Travelers and later cases, it fails to actually do so. Instead, it judges laws by whether their effects are imdirect, like the one at issue in Travelers, or direct, like that at issue in Shaw. Second, to the extent the Court does consider congressional intent, it looks primarily to the intent in passing ERISA's preemption clause, rather than looking at the more general intent of Congress in passing the Act in its entirety.

\section{Distinction Between Direct and Indirect Effects}

Travelers signaled the beginning of a new method of looking at ERISA preemption, in large part because it recognized the limited utility of section 514(a)'s language, and suggested that courts inust instead look to congressional intent to determine whether state laws should be preempted by ERISA. ${ }^{172}$ The Court failed to follow its own direction, however, by never actually examining Congress's intent in relation to the New York surcharge program at issue. Instead, the Travelers Court cited precedent in which it found ERISA preempted state laws ${ }^{173}$ and distinguished those

171. Few commentators have specifically addressed the intersection of ERISA preemption and domestic partner benefits. Two that do are Brauch, supra note 140, and Fisk, supra note 153.

ERISA preemption of state fair employment laws is closely analogous to preemption of domestic partner ordinances, since both seek to provide equality in the workplace. For an argument that state fair employment laws should not be preempted by ERISA, see Hasencamp, supra note 40 .

172. See Travelers, 514 U.S. at 655-56; see also supra notes $103-116$ and accompanying text.

173. Id. at 657-58 (citing Shaw, 463 U.S. at 97; FMC Corp. v. Holliday, 498 U.S. 52, 60 (1990); Alessi v. Raybestos-Manhattan, Inc., 451 U.S. 504, 524 (1981)). 
earlier laws from the New York statute because they directly mandate certam benefit structures. ${ }^{174}$ The Court pointed out that the law challenged in Travelers had only an "indirect economic influence"175 on employee benefit plans and thus was not preempted by ERISA.

In Travelers, the Court focused more on the indirect effect of New York's statute than it did on whether the law was one that Congress intended ERISA to preempt. Similarly, two terms later in Dillingham, the Court upheld a prevailing wage law in large part because it only created economic incentives, and did not directly "dictate the choices" of ERISA administrators. ${ }^{176}$ Aligning the law at issue in Dillingham with the one at issue in Travelers, ${ }^{177}$ the Court once again distinguished the case from cases like Shaw, where the challenged law's effect was more direct. ${ }^{178}$

While the Travelers decision seemed to require examination of congressional intent in the determination of the scope of federal preemption, it in fact implicitly created a direct-indirect dichotomy that has guided recent ERISA preemption decisions. Although the Court has denied so doing, ${ }^{179}$ recent ERISA preemption decisions consistently have divided state laws into two camps: those that have a direct effect on ERISA plans (mandating benefit structures), and those whose effect is only indirect (creating economic incentives). Laws like those challenged in Travelers and Dillingham fall into the first camp, escaping legal challenges unscathed. Laws like those at issue in Shaw and $A T A$ fit squarely in the latter camp, falling prey to preemption.

174. Id. at 658.

175. Id. at 659 .

176. Cal. Div. of Labor Standards Enforcement v. Dillingham Constr., N.A., 519 U.S. 316,333 (1997).

177. See id. at $\mathbf{3 3 0}$ ("We think that, in every relevant respect, California's prevailing wage statute is indistinguishable from New York's surcharge prograin.").

178. See id. at 328.

179. In De Buono v. NYSA-ILA Medical and Clinical Services Fund, 520 U.S. 806 (1997) the Court upheld a state tax on gross receipts of hospitals. It reversed the decision of the Court of Appeals, rejecting the lower court's holding that laws with a direct impact are preempted, while those with an indirect impact are not. See id. at 816 . In so doing, the Court referred to a passage in Travelers, in which the Court qualified its holding:

[W]e do not hold today that ERISA pre-empts only direct regulation of ERISA plans, nor could we do that with fidelity to the views expressed in our prior opinions on the matter. We acknowledge that a state law might produce such acute, albeit indirect, economic effects, by intent or otherwise, as to force an ERISA plan to adopt a certain scheme of substantive coverage or effectively restrict its choice of insurers, and that such a state law might indeed be pre-empted under $\S 514$.

Travelers, 514 U.S. at 668 (citations omitted).

While this language seens to discredit my argument above, I suggest that the Court had to find some way of reconciling its decision in Travelers with its earlier decisions, which it did not want to overnule. See supra note 73 and accompanying text. Further, my argument is not that the Court has explicitly created a direct-indirect distinction, but instead that the past few ERISA preenption decisions have come to a finding that the law at issue has only an indirect effect on ERISA plans, and is for that reason not preenpted. 
By relying on the directness of the impact a particular law has on employee benefit plans, the Supreme Court has obscured the importance of congressional intent in its preemption analysis, and has unduly simplified what should be a complex process of determining which state laws Congress intended to survive under ERISA. San Francisco's Ordinance is very similar to the New York Human Rights Law at issue in Shaw because it requires employers to provide certain benefits, namely domestic partner benefits. Under the Supreme Court's current analysis, the Court would place it immediately im the "direct impact" camp and preempt it without further discussion. Congressional intent would not factor heavily im the decision since the Ordinance fits so neatly into a group of cases doomed to preemption.

\section{Intent of the Preemption Clause v. Intent of ERISA Legislation}

When the Court does choose to examine congressional intent in this context, it fails to make the proper inquiry. At the beginning of Travelers, the Court explained that im traditional statntory construction, it first attempts to interpret the particular provision at issue to discover congressional intent. If it finds the provision to be imconclusive, the Court looks to the overall statutory scheme to determine the intent of Congress in passing the legislation as a whole. ${ }^{180}$

The Court in Travelers found the language of section 514(a) unhelpful, and correctly stated that the Court must "look mstead to the objectives of the ERISA statute as a guide to the scope of the state law that Congress understood would survive." proceeded to examine the imtent im passing section 514(a), not the statute as a whole. ${ }^{182}$ Although it stated that it planned to examine the intent in passing the "ERISA statute," in the next paragraph the Court looked at the intent in "passing § 514(a)." This inconsistency is crucial, smce the intent behind the preemption clause and the intent behind the statnte as a whole are quite different.

Congress's intent in passing section 514(a), as with most preemption clauses, was to prevent state laws from hindering the objectives of ERISA. ${ }^{183}$ The Court in Travelers quoted Ingersoll-Rand Co. $v$. $\mathrm{McClendon}$, an earlier ERISA preemption case, which found that the intent behind section 514(a) was "to ensure that plans and plan sponsors would be subject to a uniform body of benefits law; the goal was to minimize the administrative and financial burden of complying with conflicting

180. See Travelers, 514 U.S. at 655 ("Since pre-emption claims tum on Congress's intent, we begin as we do in any exercise of statutory construction with the text of the provision in question, and inove on, as need be, to the structure and purpose of the Act in which it occurs." (citations omitted)).

181. Id. at 656 .

182. Id. ("We have found that in passing $\$ 514(\mathrm{a})$, Congress intended ....")

183. See supra note 36. 
directives among States or between States and the Federal Government."184 This construction of the goals behind section 514(a) meshes with the concerns voiced by the sponsors of the ERISA bill, ${ }^{185}$ who sought to protect ERISA from state laws aimed at weakening its effect.

On the other hand, the intent of Congress in passing ERISA as a whole was to protect employees from mequitable treatment im the area of employee benefit plans. ERISA's primary goal was to provide security for plan participants and beneficiaries by federally regulating the administration of pension plans. ${ }^{186}$ This goal is wholly separate and distinct from the more specific goal in enacting ERISA's preemption clause. Yet courts continually conflate the two, substituting congressional intent in passing section 514(a) with intent in enacting ERISA as a whole. ${ }^{187}$ Unsurprisingly, by focusing on the intent behind the preemption clause, instead of the intent of the legislation generally, courts are too willing to preempt state and local laws.

For example, in $A T A$, Judge Wilken relied on the language from Travelers quoted above. She first stated that the court must look to the "objectives of the ERISA statute" and then in the next sentence found that the "purpose of the ERISA preemption clause "was to avoid a multiplicity of regulations in order to permit the nationally uniform administration of employee benefit plans." "188 Thus, Judge Wilken's opinion demonstrates that the lower courts have unquestioningly followed the Travelers Court's move from examining the statute to examining the clause, reinforcing that mistake.

The ramifications of this confiation are not mitially obvious, but closer scrutiny reveals they are in fact quite dramatic. If one looks to the intent of the statute, the issue becomes whether a state law interferes with ERISA's goal of protection and equitable treatment of employees and their beneficiaries. If one looks instead to the mtent of the preemption clause, then the question is whether a state law impedes uniformity and administrative costs of complying with multiple regulations. Courts have primarily done the latter, finding state laws preempted if they disturb uniform national distribution of employee benefit plans in any way. ${ }^{189}$

To some extent, courts should look at both of these goals, since Congress intended both to protect employees and to minimize

\footnotetext{
184. 498 U.S. 133, 142 (1990).

185. See supra note 35 .

186. The text of ERISA itself asserts that "it is therefore desirable in the interests of employees and their beneficiarics, for the protection of the revcnue of the United States, and to provide for the free fiow of commerce, that minimum standards be provided assuring the equitable character of such plans and their financial soundness." 29 U.S.C. \$1001(a) (1994); see also supra note 35.

187. See, e.g., Travelers, 514 U.S. 656; Air Transp. Ass'n of Am. v. City of San Francisco, 992 F. Supp. 1149, 1166-67 (N.D. Cal. 1998).

188. $A T A, 992$ F. Supp. at 1166-67.

189. See, e.g., Travelers, 514 U.S. at 656-57; $A T A, 992$ F. Supp. at 1166.
} 
administrative burdens through uniform regulation. However, in relying primarily on Congress's intent in enacting section 514(a), courts have failed to consider that its purpose is primarily instrumental. That is, ERISA's preemption clause, with its goal of uniformity and administrative ease, exists only to fulfill the larger and more crucial goal of ERISA itself: protecting plan participants and beneficiaries. ${ }^{190}$

The instrumental character of ERISA's preemption clause makes intuitive sense, simce preemption clauses tend to operate to protect legislation from interference by conflicting state laws, thus working to ensure the legislation's ultimate objectives will be inet. The expansive language used in ERISA's preemption clause, coupled with the difficulty of defining the phrase "relate to," however, have encouraged courts to rely heavily on congressional intent in enacting that particular provision, instead of examining the purpose of ERISA generally.

Courts' overrehiance on minimizing the administrative costs of complying with conflicting state regulations leads to preemption of state and local laws that actually serve the objectives of ERISA by protecting employees from inequitable treatment. Presumably, Congress did not envision, in enacting ERISA, that cities or states could consider providing domestic partner benefits as one method of ensuring the "equitable character"191 of employee benefit plans. The definition of equitable treatment has shifted since the time of ERISA's passage, and San Francisco clearly has the interests of its citizens, as employees, at heart in enacting the Ordinance. If courts continue to focus on the intent of Congress as evidenced by ERISA's preemption clause, instead of looking to congressional intent more generally im enacting ERISA, they will inappropriately rest their decisions on an instrumental goal (uniformity), instead of inoving beyond that to the primary goal behind ERISA (protection of einployees and their beneficiaries).

\section{Counterarguments}

Soine may suggest that iny argument that San Francisco's Equal Benefits Ordinance should not be preempted by ERISA cannot survive under certain circumstances. For instance, what if a state or locality adopts an ordinance that prohibits domestic partner benefits? If the federal government amended ERISA to mandate benefits for domestic partners, would I still be concerned about states' rights? Addressing these anticipated challenges will help clarify my position.

190. As one commentator put it, "the use of ERISA's preemption clause to protect employers and ERISA benefit plans from conflicting state laws is only an ancillary purpose to the primary purpose of protecting employees' benefits from the employers' administrative and funding abuses." Larry J. Pittman, ERISA's Preemption Clause and the Health Care Industry: An Abdication of Judicial LawCreating Authority, 46 FLA. L. REv. 355, 358 (1994), quoted in Harshbarger, supra note 166, at 217.

191. 29 U.S.C. § 1001(a) (1994). 
First, a law that prohibits companies from providing domestic partner benefits to their employees would contradict the primary purpose of ERISA, which is to protect employees and their beneficiaries from the loss of benefits. Such a law would narrow the range of people who are ehigible for employee benefits, whereas San Francisco's Ordinance expands the definition of who must be considered a beneficiary. ${ }^{192}$ Further, ERISA itself states that one of its purposes is to ensure the "equitable character" of employee benefits. ${ }^{193}$ San Francisco's law encourages equality by requiring companies not to discriminate between spouses and domestic partners, whereas a law prohibiting companies from providing domestic partner benefits flatly discriminates against employees with domestic partners. Nor would a law that prohibits domestic partner benefits further the secondary goal (voiced in support of ERISA's broad preemption clause) of protecting companies from conflicting local laws, since many companies already provide such benefits and would have to eliminate their benefits to comply with a certain state or municipality's law. Thus, such a law is very different from San Francisco's Ordinance, and likely would not be upheld under my proposed analysis of ERISA preemption, since it furthers no goal of ERISA.

Second, if Congress enacted a law that mandates domestic partner benefits, this would not affect my position. This is because my support for San Francisco's Ordinance does not rely on a theory of states' rights per se. In other words, my argument is not that the Ordinance should stand simply because states should have the power to regulate the employment relationship. Were this to be the case, ERISA itself would be under attack, since it regulates many aspects of the employment relationship that were once left to the states. Instead, my argument is that where Congress has not acted to regulate a specific area, and states have traditionally regulated that subject, local and state governments should not be barred froin so doing because of an irrationally-broad preemption clause. This is especially true where, as here, the local law aims to combat discrimination in an area currently not addressed by federal law. ${ }^{194}$ If Congress acts to provide the protection that San Francisco currently provides to its citizens by enacting a law that mandates domestic partner benefits, this would simply support my theory that many new forms of discrimination must be addressed on the local level before being embraced nationally. Once Congress has exphitly regulated in the area and determined how beneficiaries of employee benefits should be determined, there would be less room for states to act. This does not concern me; what does concern me is the inability of states to regulate the provision of employee benefits when Congress has also failed to do so, yet

192. See supra note 94 and accompanying text.

193. See supra note 191.

194. See supra note 27 and accompanying text. 
has preempted the field entirely. It is this narrow issue that this Comment seeks to address.

\section{IV \\ SoLUTIONS}

In the previous Part, I focused on problems with ERISA preemption, pointing out the error in legislative drafting that created an overly broad preemption clause, and highlighting ways in which the Supreme Court has failed to examine the proper issues in its efforts to define the scope of ERISA preemption. In this Part, I will look at some judicial and legislative solutions to these problems, with specific consideration of San Francisco's Ordinance. Fimally, I will outline ways in which ERISA preemption should be changed to allow laws like San Francisco's to stand.

\section{A. Reform of ERISA Preemption: Judicial Possibilities}

\section{Correction of the Supreme Court's Mistakes}

The Supreme Court should refine its ERISA preemption analysis beyond the nonliteral approach taken in Travelers. Many have hailed Travelers and its progeny, claiming that the Court has finally narrowed ERISA preemption to its proper scope. ${ }^{195}$ A careful examination of the decisions, however, illustrates that the Court has made two crucial mistakes. First, it has applied a simplistic, direct-indirect distinction to the complex question of preemption, relying on earlier cases in order to distinguish new ones. Second, the Court has relied too heavily on the goal of uniformity expressed in enacting section 514(a), and has overlooked the more important and decisive intent of Congress to protect employees.

The key to correcting the Court's first mistake is to explicitly acknowledge that the Travelers decision marked a new approacli to ERISA preemption, rejecting the old reliance on textual literalism. To do so, the Court cannot continue to uphold its earlier decisions as good law, merely distinguishing them from the case at hand, for this fuels obfuscation of congressional intent, as evidenced by the direct-indirect distinction that lurks beneath the surface of the Travelers and Dillingham decisions. ${ }^{196}$ Instead, the Court must recognize that it no longer follows the text of section 514(a) in the same unquestioning way it once did, and explicitly overrule (or at least call into question) its earlier holdings.

195. E.g., Catherine L. Fisk, The Last Article About the Language of ERISA Preemption? A Case Study of the Failure of Textualism, 33 HARV. J. ON LEG1s. 35 (1996); Margaret G. Farrell, ERISA Preemption and Regulation of Managed Health Care: The Case for Managed Federalism, 23 AM. J.L. \& MED. 251 (1997); James Saya, Note, Removing a Roadblock to Reforming Health Care: New York State Conference of Blue Cross \& Blue Shield Plans y. Travelers Insurance Company, 3 ConN. INs. L.J. 127 (1996-1997).

196. See supra notes 172-179 and accompanying text. 
At least one member of the Court, Justice Scalia, has already done so. He wrote a concurring opinion in Dillingham (joined by Justice Ginsburg) criticizing the Court's failure to provide clear guidance in the area of ERISA preemption. Justice Scalia rightly argued:

Today's opinion is no more likely than our earlier ones . . . to bring clarity to this field - precisely because it does obeisance to all our prior cases, instead of acknowledging that the criteria set forth in some of them have in effect been abandoned. Our earlier cases sought to apply faithfully the statutory prescription that state laws are pre-einpted "insofar as they ... relate to any einployee benefit plan." .. . But applying the "relate to" provision according to its terms was a project doomed to failure, smce, as many a curbstone philosopher has observed, everything is related to everything else....

I think it would greatly assist our function of clarifying the law if we simply acknowledged that our first take on this statute was wrong; that the "relate to" clause of the pre-emption provision is meant, not to set forth a test for pre-emption, but rather to identify the field in which ordinary field pre-einption appliesnamely, the field of laws regulating "einployee benefit Straplan[s] it may seem that Justices Scalia and Ginsburg would agree with one another, it is stranger still to find Justice Scalia rejecting formal textual interpretation of a seemingly straightforward statutory provision. ${ }^{198}$ True to forn, however, Justice Scalia chose to tell it like it is: if the Court is going to treat ERISA preemption in a completely new way, he wanted to exphcitly recognize that the earlier decisions were wrong and are no longer good law.

Justice Scalia went one step further than simply rejecting the earlier, uncritical cases that struck down state laws in the face of ERISA's broad preemption clause. He proposed that what the Court is currently engaging in bears very little relationship to the text of section 514(a). "I think it accurately describes our current ERISA jurisprudence to say that we apply ordinary field pre-emption, and, of course, ordinary conflict pre-emption. Nothing more mysterious than that; and except as establishing that, 'relates

197. Cal. Div. of Labor Standards Enforcement v. Dillingham Constr., N.A., 519 U.S. 316, 335 (1997) (Scalia, J., concurring).

198. The most likely explanation for Scalia's rejection of literal textualism is his commitment to federalism. The Court's rccent turn in Travelers probably reflects an interest in asserting states' rights and limiting the influence of federal legislation over state and local laws. An interesting question would arise if a case hike $A T A$ were to reach the Supreme Court, for it would raise federalism issues within the context of support for sexual orientation nondiscrimination, thus putting conservative Justices like Scalia in a difficult position. Would he assert state rights and uphold the Ordinance, or draw the line at such a progressive law and invalidate San Francisco's attempt to assert its morality on private companies? Because the City chose not to appeal the ERISA decision made by Judge Wilken (presumably because they believed it was a losing battle), this scenario is pure speculation and will not be realized with this case. 
to' is irrelevant."199 Justice Scalia, in essence, removed section 514(a) from the picture, and claimed that the Court was applying traditional implied preemption principles. Such a move would cure ERISA preemption of its lingering reliance on the directness of a law's relationship to employee benefit plans, and open the door for an analysis that focuses more explicitly on congressional intent, as is done under implied preemption principles.

This leads us to the Court's second mistake: looking at the intent behind section 514(a) instead of the intent behind ERISA itself. In focusing primarily on the goal of uniformity and administrative ease, the Court has unnecessarily expanded the scope of ERISA's already broad preemptive reach. This is not to say that the goal of avoiding conflicting state regulations is unimportant or useless, but only that the Court must weigh it against other, more pressing objectives of protecting employees from inequitable treatment.

The goal enunciated by Congress when presenting section 514(a), easing administrative burdens and costs through uniformity, does have an important role to play in the Court's analysis. Congress's primary goal in enacting ERISA was to protect plan participants and beneficiaries by federally regulatimg pension plan administration. One way to ensure sucl protection was to preempt the field for federal action, thus eliminating the threat of state laws that conflict with federal regulations. Due to the Supremacy Clause, however, this preemption occurs automatically with the enactment of any sweeping federal legislation. Furthernore, because ERISA does not contain any substantive regulation of employee welfare plans (benefit plans that provide health care, and so forth), but only addresses pension plans, there is no concern that state laws addressing welfare plans will interfere with (nonexistent) federal regulations. ${ }^{200}$

Therefore, we must look elsewliere to find a reason for applying section 514(a) to employee welfare plans. Importantly, Congress recognized that employers would be better able and willing to provide benefit plans if they were ouly subject to one (federal) regulatory scheme, instead of having to follow eacli state's or municipality's varying regulations as to employee benefit plans. ${ }^{201}$ This interest in protecting

199. Dillingham, 519 U.S. at 335 (Scalia, J., concurring) (citations omitted). Field preemption refers to preemption of state laws that act within a field already regulated or oceupied by federal law. Conflict preemption refers to preemption of state laws that conflict with the objectives of federal legislation. Martin, supra note 38, at 1235-36. Field and conflict preemption are types of implied precmption.

200. Irish \& Cohen make this point thus:

Without federal regulation of the substantive content of welfare plans, preemption by ERISA

in the welfare area offers only the benefit of scant but uniform nationwide welfare plan administration ...., countered by the substantial burden of a regulatory vacuum that is filled, if at all, by ad hoc judicial creation of substantive rules. This is far different than the policy balance Congress struck in preempting state pension plan regulation.

Irish \& Cohen, supra note 161, at 147.

201. See supra note 35 . 
employers from having to comply with conflicting state regulations encouraged Congress to pass such a broadly worded preemption clause.

ERISA's preeinption clause may seek to create a uniform federal regulation of employee benefit plans, but it does so only in order to accomplish the primary goal behind ERISA, protecting einployees by maximizing access to secure benefit plans. As one of the bill's sponsors pointed out during legislative discussion, by "eliminating the threat of conflicting and inconsistent State and local regulation," section 514(a) inerely "round[s] out the protection afforded participants."202 Because the goal of uniformity is ancillary to the more fundamental objective of protecting plan participants, the Court should not weigh it as heavily when determining if a particular state law should be preempted by ERISA. Instead, it shonld balance the two goals but place more weight on the essential objective of securing the interests of employees and their beneficiaries. ${ }^{203}$

\section{Application of the Proposed Remedy to San Francisco's Ordinance}

If the Court would apply these principles to the Ordinance, it could save the Ordinance from ERISA preemption. First, the Ordinance's goal is to protect employees and beneficiaries by providing benefits on a nondiscriminatory basis, thus meshing with ERISA's primary goal of protecting plan participants. ${ }^{204}$ Admittedly, the fit between ERISA's original goal, which focused on the security of benefit plan funds, and the Ordinance's goal, which focuses on protecting a certain group of citizens from discrimination, is not tight. The general goal of both laws, however, is to protect einployees froin unequal treatinent; San Francisco should have the freedom to define what this ineans for its citizens.

Second, the Ordinance does require einployers to provide a different level of benefits in San Francisco than they may provide elsewhere, increasing administrative costs by forcing einployers to adjust their benefit plans for domestic partners. ${ }^{205}$ United and ATA focused on this concern, arguing that international airlines should not be subject to different local regulations at every airport they use. ${ }^{206}$ These costs are minimal, though, given the nature of the requirement. The Ordinance simply requires

202. 120 CoNG. Rec. 29,197 (1974) (statement of Rep. Dent).

203. For a similar approach, see infra note 214.

204. See Hasencamp, supra note 40 , at 587-88 ("Equal treatment, when enforceable, is a substantial employee protection; nondiscriminatory administration of employee benefit plans is an essential part of this protection.").

205. Because the court in $A T A$ held that San Francisco can only apply its Ordinance to employers when they are working on contracts directly for the City, multistate comparies only have to comply with the Ordinance when they do business for the City. See Air Transp. Ass'n of Am. v. City of San Francisco, 992 F. Supp. 1149, 1165 (N.D. Cal. 1998). This provision minimizes the extent to which companies may be subject to varying or conflicting regulations, since most work for the City will take place in or near San Francisco, and only be subject to San Francisco's laws.

206. See, e.g., Podmolik, supra note 91. 
employers to add a category of people eligible to be beneficiaries of benefit plans: domestic partners. ${ }^{207}$ Providing domestic partner benefits does not require major clianges to central elements of benefit plans, and employers can, if necessary, accommodate it through separate, stand-alone plans. ${ }^{208}$ The process is fairly simple: instead of asking if an employee has a spouse, the question becomes whether an employee has a spouse or a domestic partner (and creating a form for so proving, if found necessary). The real issue underlying this dispute is whether forcing companies like United to provide domestic partner benefits will mstead cause them to eliminate or reduce the overall benefits they provide to their employees, thus hindering the goals of ERISA. This seems unlikely since United ultimately chose to provide domestic partner benefits voluntarily, with no apparent decrease in benefit packages overall. ${ }^{209}$ Weighing the minor administrative costs of providing such benefits against the important goal of equality in einployee benefit administration, ${ }^{210}$ it is clear that the Ordinance does not threaten ERISA's goals and thus should not be preeinpted.

Laurie Hasencamp, in examining ERISA preemption of state fair employment laws, states that

[s]tate fair employinent laws are not the type of state law at which section [514(a)] was aimed: their goals are harmonious witl those of ERISA and they do not substantially increase the costs of administration. To the extent that they do, lowever, any increased cost is offset by the increased benefit of working in a nondiscriminatory environment. ${ }^{211}$

207. One need not look far to find evidence of the minimal costs associated with providing domestic partner benefits. United Airlines itself allows employees in New Zealand, pursuant to a New Zealand Human Rights Commission ruling, to name anyone as a beneficiary. See Irvine, supra note 13. Similarly, Qantas Airways has provided benefits and travel passes for its Australian einployees' "nominated beneficiaries" for years. El Al airline in Israel was forced to offer domestic partner benefits to its employees in 1994, and Air Canada has been providing doinestic partner benefits to its estimated 18,000 employees since early 1996. See id. These examples show that requiring the provision of doinestic partner benefits would not unreasonably burden benefit plan administration, even if only certain localities require it.

208. See S.F., CAL., Admm. Code § 12B.1; ATA, 992 F. Supp. at 1169-70.

209. See Epstein, supra note 113.

210. Nonmonetary benefits could offset some of the administrative costs of complying with the Ordinance. Many studies have shown that the increased cost of providing doinestic partner benefits is minimal, while offering nondiscriminatory employee benefit packages attracts a more diverse workforce and results in value to the employer. See, e.g., Lambda Legal Def. \& Educ. Fund, Basic Facts About Domestic Partner Benefits, at htt://www.lambdalegal.org/ cgi-bin/pages/documents/record?rccord=17 (Sept. 27, 1997); Lambda Legal Def. \& Educ. Fund, Details About Domestic Partner Benefits, at http://www.lambdalegal.org/ cgi-bin/pages/documents/record?record=18 (Sept. 28, 1997).

211. Hasencamp, supra note 40 , at 601 . Hasencamp has proposed that, where Congress has not explicitly stated its intent to preempt a certain type of law, to determine whether a particular law should be preempted, 
This analysis is similar to the one I propose, and arrives at the same conclusion. San Francisco's Ordinance is a type of fair employment law, for it requires nondiscrimination in the provision of employee benefits between spouses and domestic partners. Its goals and administrative costs are similar to those of state fair employment laws, and for the same reasons should be immune from ERISA preemption.

\section{Inability of the Supreme Court to Move Beyond the Statutory Command}

Once solutions have been identified, the next question is whether there is a possibility of their enactment. Justice Scalia provided hope that the Supreme Court may be able to fully move beyond the problematic precedents that relied on the broad language of section 514(a) to invalidate many state laws. Unfortunately, he currently has only one follower, and it seems doubtful that the Court will soon agree with his desire to elimmate consideration of ERISA's statutory language and rely solely on implied preemption principles.

The Court has traveled a long distance in limiting in its ERISA preemption analysis from that displayed in Shaw to the much narrower interpretation found in Travelers. The common-sense, intent-based approach embraced in Travelers seems to have solved many of the problems inherent in section 514(a)'s expansive language. On closer examination, however, the Travelers approach fails to provide adequate foundation for ERISA preemption jurisprudence, and fails to solve the problems faced by laws that may have a direct effect on employee benefit plans, but in fact do not threaten ERISA's objectives in any substantive way.

While it is possible for the Court to approach ERISA preemption in a manner that would allow ordinances like San Francisco's to survive, it is doubtful that this will happen. The Court is unlikely to stray from the textual guidance of section 514(a) any more than it has recently. The "relates to" language in ERISA's preemption clause is simply too powerful to overcome with judicial creativity. While many commentators have expressed dissatisfaction with the Court's ERISA preemption

courts should examine the following factors: The degree to which the goals and effects of the state law are harmonious with ERISA; the connection of the state law with other federal law, and any intent in the federal law to preserve that state law [this goes to the author's argument that Title VII's interest in strong state antidiscrimination laws forces the finding that ERISA does not preempt state fair employment laws]; the degree to which preeunption will have an undesirable chilling effect on further enactment of state laws of a certain typc; and the increased costs to employers of compliance with the state law, as well as any offsetting nonmonetary benefits that might compensate for any decrease in employee wages or monetary benefits.

Id. at 600 . These factors include the two goals I have discussed: harmony with the purposes behind ERISA, and minimizing the costs of compliance with multiple laws. 
jurisprudence, none has been able to argue that an ordinance like San Francisco's would not, realistically, suffer preemption. ${ }^{212}$

Professor Catherine Fisk argues that the Supreme Court must "abandon[] its slavish devotion to literalist textualism in interpreting ERISA's broad preemption provision and instead adopt[] a pragmatic approach. ${ }^{213}$ She suggests that the Court did this in Travelers, and can continue to embrace a pragmatic approach by asking "whether preemption of state law will serve the objectives of ERISA."214 Fisk believes that it is the job of the courts, not Congress, to determine the proper balance between federal and state law. This is so, Fisk argues, because Congress cannot make these decisions through legislation with sufficient specificity to encompass every state law challenge that may arise. ${ }^{215}$ This seems evidently true, as does her proposition that congressional amendinent of section 514(a)'s language is extremely unlikely. ${ }^{216}$ Fisk admits that her conclusion is functional: if Congress will not change its irrational preemption language, the courts will have to ignore it in order to produce rational law. 217

I agree with Fisk's desire to stray from ERISA's preemption language, but cannot embrace her belief in the ability of judges to fix a statutory failure. First, Fisk claims she may be writing the "last article" about the language of ERISA preemption, simce she believes the Travelers decision corrected the Court's mistaken reliance on textualism. As I have shown, Travelers did not go far enough im divorcing itself from the language of section 514(a), since preemption of state laws still turns on the directness of the relation to employee benefit plans. Second, Fisk is overly optimistic about the ability and willinguess of courts to ignore the powerful

212. Two commentators have addressed ERISA preemption in relation to San Francisco's Ordinance. One article argues strongly for the position that ERISA preempts the Ordinance, even after 0Travelers, a position that is almost impossible to contest. See Brauch, supra note 140 . A second commentator, although sympathetic to the Ordinance, is only able to defend it by arguing that preemption would impair the operation of another federal law, the Defense of Marriage Act. She thus circumvents the direct question of whether ERISA preempts the Ordinance. See Fisk, supra note 153, at 286.

213. Fisk, supra note 195 , at 39-40.

214. Id. at 40 . Fisk's pragmatic approach closely resembles the approach I have argued for above, focusing on weighing the goals of ERISA.

The question should not be the meaning of "relates to," but rather whether allowing employers to be subject to state regulation would defeat the goals of protecting employee expectations in receiving benefits. The ERISA preemption inquiry requires an appraisal of the need for national uniformity balanced against the advantages of regulations at the state level. This calls for pragmatism.

Id. at $90-91$.

215. Id. at 96 ("Even if Congress had had time to consider the implications of section 514's language carefully, it could not have formulated ex ante a policy that would decide all cases.").

216. Id. at 99-100.

217. Id. at 91 ("My argument is entirely functional: courts should modify ERISA preemption doctrine because the current doctrine makes no pohcy sense and is not dictated by the statute."). 
and seemingly manifest direction from Congress that ERISA preempt all state laws that "relate to" employee benefit plans. ${ }^{218}$ Courts can only stretch the meaning of the term "relates to" so far before the logical string snaps, and the statutory language demands preemption of otherwise harmless laws. Fisk's pragmatic approach may permit courts to uphold laws such as the one at issue in Travelers, but San Francisco's Ordinance will not be saved by judicial action alone.

\section{B. Reform of ERISA Preemption: Legislative Possibilities}

In the absence of viable judicial solutions, congressional aniendinent to ERISA's preemption clause is the only practical answer. Section 514(a)'s broad language originally created the ERISA preemption problems, and correction of its terms is the logical antidote. Two challenges to legislative amendinent immediately arise. First, Congress has not substantively amended the section to date, indicating that it is unlikely to do so. Second, amendinent raises the problem addressed above by Fisk: it is difficult to legislate ex ante the proper relationship between state and federal law.

\section{Forms of Statutory Amendment}

Section 514(a) could be amended in a number of ways. The most immediately obvious possibility would be to narrow preemption to only those subjects covered by ERISA, as the House and Senate versions of the bill originally provided. ${ }^{219}$ This would preserve federal regulation of pension plan administration, but would allow states to regulate some areas of employee benefits that do not conflict with ERISA's objectives. Because ERISA does not regulate employee welfare plans at all, it would not expressly preempt the San Francisco Ordinance. The Ordinance would only face field and conflict preemption, which it presumably could survive. Unfortunately, amending section 514(a) in this way could hold dangers which one cannot anticipate at the legislative stage, as Fisk warns. ${ }^{220}$ It might have undesired effects, either by still preempting too broadly, or by allowing too many state laws that relate to employee benefit plans to

218. Intcrestingly, after writing the Last Article soon after Travelers was decided, Fisk wrote her Domestic Partnership article in 1998, arguing that laws like San Francisco's should not be preempted because doing so would impair or modify another federal law, the Defense of Marriage Act. Fisk did not argue that courts should follow her pragmatic approach and uphold the Ordinance, but instead found a loophole in ERISA, which does not preempt state law to the extent that doing so would impair or modify any federal law. See Fisk, supra note 153; see also 29 U.S.C. § 1144(d) (1994). Fisk's reliance on an obscure provision of ERISA, and her unwillingness to argue that the Ordinance on its face does not preempt ERISA, best illustrates the practical weakness of her argument.

219. See supra notes 163-164.

220. See Fisk, supra note 195, at 96. 
survive, as Congress inust have originally feared in rejecting such a provision for a much broader one.

A second potential amendment would provide an exeinption froin preemption for state antidiscrimination and fair employment laws. ${ }^{221}$ This would address the particular problem of preemption of laws intended to afford equality to employees, such as the Ordinance. It would not address the larger problem of ERISA preemption, however, nor would it save progressive state legislation in other arenas that are equally nonthreatening.

The best solution would be to remove section 514(a) altogether, and allow traditional implied preenption principles to guide case-by-case judicial decisions about the proper relationship between state and federal law. ${ }^{222}$ Because Congress in drafting ERISA made its desire to preeinpt the field of pension plan administration abundantly clear, removal of section 514(a) would not allow state laws that conflict with ERISA's purposes to survive. Further, as Justice Scalia poimted out in his concurrence in Dillingham, the Court has already resorted to traditional field and conflict preemption principles (subject to the limitations that remain as long as section 514(a) is in effect). ${ }^{223}$ Freed of the constraints imposed by section 514(a)'s broad phraseology, courts could properly weigh congressional intent to determine the scope of preemption that is appropriate for ERISA, instead of being fettered by poorly considered statutory language.

\section{Possibility of Congressional Action}

Proposing a legislative solution is often an appropriate conclusion, but it faces the same problem as judicial solutions: the slim possibility of realization. Legislative solutions, however, are more feasible than judicial solutions (which are constrained by ERISA's plaim text). Moreover, though soine commentators have doubted Congress's willingness to amend section 514(a) ${ }^{224}$ some congressional action has occurred in response to specific problems applying ERISA's preemption clause. Congress has twice added to section 514 specific exemptions from preemption for particular laws. ${ }^{225}$

In 1974, Hawaii enacted a statute requiring employers to provide employees with prepaid health imsurance, ${ }^{226}$ which ERISA later preempted. ${ }^{227}$ Eight years after the statute's enactment, Congress agreed to amend section 514 to include a new exception specifically applicable ouly to Hawaii's

221. See Hasencamp, supra note 40 , at 600 .

222. See Fisk, supra note 195, at 96 .

223. Dillingham, Cal. Div. of Labor Standards Enforcement v. Dillingham Constr., N.A., 519 U.S. 316,335 (1997) (Scalia, J., concurring).

224. See, e.g., Fisk, supra note 195, at 99-100.

225. See infra notes 226-231 and accompanying text.

226. See Hawaii Prepaid Health Care Act, 1974 Haw. Sess. Laws cb. $210, \S 1$ (codified as amended at Hawam Rev. Stat. $\$ \$ 393-1$ to 393-51 (Michie, WESTLAW through 1999 Reg. Sess.)).

227. See Standard Oil Co. v. Agsalud, 442 F. Supp. 695 (N.D. Cal. 1977), aff d, 633 F.2d 760 (9th Cir. 1980), aff'd mem., 454 U.S. 801 (1981). 
law: "subsection [514](a) ... shall not apply to the Hawaii Prepaid Health Care Act." 228 Explaining this amendment to ERISA's preemption provision, the Senate Fimance Committee stated that the preemption of Hawaii's statute by the Act was "inadvertent."2229

Congress also amended ERISA in response to preemption of a series of cases involving family property. ${ }^{230}$ The new exemption allows "qualified domestic relations orders," such as those relating to child support, alimony, or family property rights, to escape preemption. ${ }^{231}$

These exemptions from ERISA preemption, enacted in response to particular problems that arose out of the strict application of section 514(a), illustrate that Congress is capable of amending the Act when it becomes clear that the preemption clause threatens desirable laws. It is uncertain whether Congress will amend section 514(a), repairing the problematic "relates to" language that is the core obstacle in reforming ERISA preemption. It may be doubtful, but such legislative amendment is sorely needed if ERISA preemption is to be limited so that well-intentioned state and local laws can survive.

\section{CONCLUSION}

ATA's successful challenge to San Francisco's Ordinance highlights the problematic nature of ERISA preemption. Though San Francisco's Ordinance has almost nothing to do with the subjects regulated by the Act, ERISA's broad preemption language prevents San Francisco from protecting its citizens by enacting a law aimed at preventing discrimination. Even after Travelers narrowed the breadth of ERISA's preemptive reach, the Act still preempts ordmances like San Francisco's. The Supreme Court has taken steps in the right direction by recognizing the disutility of ERISA's preemption clause, but it has failed to properly weigh the interests at stake when the Act threatens to preempt state laws applying to employee benefit plans. Further, the Court has not been able to sufficiently avoid section 514(a)'s extraordinarily sweeping language, nor does it seem possible to analyze ERISA preemption without inevitably addressing the "relates to" question.

The combination of legislative and judicial error has provided us with an absurd situation: local governments like San Francisco, which seek to protect their employees from discrimination im employee benefits, cannot fully do so under current ERISA preemption rulings. Instead, they cur-

\footnotetext{
228. 29 U.S.C. $\S 1144(b)(5)(A)(1994)$.

229. S. REP. No. 97-646, pt. II.D. (1982), reprinted in 1982 U.S.C.C.A.N. 4580.

230. See, e.g., Stone v. Stone, 450 F. Supp. 919 (N.D. Cal. 1978), aff d, 632 F.2d 740 (9th Cir. 1980).

231. See 29 U.S.C. $\$ 1144(b)(7)(1994)$.
} 
rently must limit their laws to avoid preemption, or face successful legal challenges that gut much of the law's anticipated nondiscriminatory effect.

Judicial efforts to work around ERISA's broad preemption clause have not succeeded in protecting laws like San Francisco's Ordinance. Because the current state of ERISA preemption prevents states from enacting laws that are in line with ERISA's general purposes of einployee protection, Congress needs to legislatively delete section 514(a) so that ERISA's preemptive scope does not swallow the entire field of employee benefit plans. Only then will state and local governments be free to protect their citizenry from newly recognized forms of discrimination, without the threat of federal preemption. 
